\title{
ARTICLES
}

\section{DEFERRING FOR JUSTICE: HOW ADMINISTRATIVE AGENCIES CAN SOLVE THE EMPLOYMENT DISPUTE QUAGMIRE BY ENDORSING AN IMPROVED ARBITRATION SYSTEM}

\author{
Zev J. Eigen \& David Sherwyn*
}

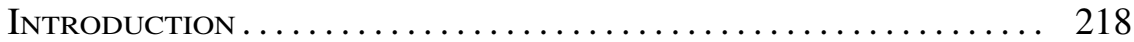

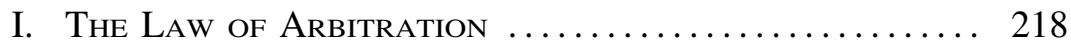

A. An Overview of the Law ...................... 219

B. Class Action Waivers......................... 223

C. Why Employers Implement Mandatory Arbitration Policies..................................... 229

D. Do Class Action Waivers Harm Employees? ........ 230

II. What's Wrong With the Current System? ......... 232

A. The EEOC Process .......................... 232

B. EEOC Litigation ........................... 236

C. EEOC Investigations ...................... 247

III. A Theoretical Framework to Contend that

EMPlOyment Litigation is BAD FOR GoOd Actors AND

GOOD FOR BAD ACTORS ...................... 252

A. The Haves Still Come Out Ahead .............. 252

B. The Theoretical Framework for Dispute Resolution

Fairness ................................... 253

IV. The Empirical Studies .......................... 259

V. The Remedy................................. 268

A. Due Process ............................ 268

B. Arbitrator Neutrality ...................... 270

C. The Development of the Law.................. 271

D. Class Actions ............................ 271

E. The Mandatory Arbitration Act (the MAA)........ 272

Conclusion....................................... 272

* Zev J. Eigen, JD, PhD, Global Director of Data Analytics at Littler Mendelson, formerly Professor at Northwestern University School of Law.

David Sherwyn, JD, is the John and Melissa Ceriale Professor of Hospitality Human Resources, Academic Director of the Cornell Institute for Hospitality Labor and Employment Relations and Stephen H. Weiss Presidential Fellow. 


\section{INTRODUCTION}

When it comes to the issue of pre-dispute mandatory arbitration, the concept of attaining justice for all partie $\mathrm{n}$ a vacuum instead of in comparison to the fall back-the litigation and agency adjudication processes. In this Article, we address each of the components of arbitration, but in context to the alternative and thus, conclude that a fixed arbitration system will provide the type of justice unavailable in the current system.

The issue of pre-dispute mandatory arbitration of discrimination, and other employment, cases has been a topic of discussion for over twenty-five years. Initially, the question was simply one of legalitycould employers actually require employees, as a condition of employment, to agree to arbitrate all their claims? Of course, this question was simple if the answer was no. Yes, however, was more complicated. What did the agreements need to contain to be enforceable? Did they apply in the union setting? Could they include class action waivers? As explained more fully below, most of the legal issues have been resolved and the remaining one - the enforceability of class action waivers - has created a split in the circuits that hopefully will be resolved in the near future. Now that the law is mostly settled, the question that remains is easy to state and difficult to answer-should pre-dispute mandatory arbitration agreements be enforceable? The answer, we contend, is yes. In fact, we take the argument a step further and argue that not only should the administrative agencies stop contesting arbitration, they should enact policies of deferral.

This Article contends that in order to provide a path to justice, the administrative agencies that enforce employment laws should no longer contest cases, but instead should defer them to arbitration. In Part I, we give an overview of the law. In Part II, we identify the problems with the current system for adjudicating employment disputes by examining the Equal Employment Opportunity Commission (EEOC) and litigation process. In Part III, we provide a theoretical argument as to why the EEOC/ litigation process is flawed and should be replaced. In Part IV, we identify, contest, and address the arguments against pre-dispute arbitration. Finally, in Part V, we propose a new system to provide access to justice for employees seeking redress under the law.

\section{The Law of Arbitration}

A full discussion of the law of arbitration is beyond the scope of this article and can be found in numerous other law review articles. ${ }^{1}$ That

1 See generally David Sherwyn, J. Bruce Tracey \& Zev J. Eigen, In Defense of Mandatory Arbitration of Employment Disputes: Saving the Baby, Tossing Out the Bath 
said, it is important to provide a baseline for understanding if pre-dispute mandatory arbitration is lawful, with or without class action waivers.

\section{A. An Overview of the Law}

The evolution of the law is complex and somewhat convoluted. In Alexander v. Gardner-Denver, a 1973 case, a union member employee was fired and arbitrated his grievance under his union contract. ${ }^{2}$ At the arbitration, the employee alleged the employer terminated the employee because of his race. ${ }^{3}$ The arbitrator denied the grievance and held there was cause for termination. ${ }^{4}$ Subsequently, the employee filed a race discrimination case in federal court, where the employer argued that (1) the arbitration was the exclusive forum for the dispute, and regardless of that, (2) the employee had chosen to go to arbitration and was not entitled to the proverbial second bite of the apple. ${ }^{5}$ On appeal, the United States Supreme Court rejected the employer's argument and found that the arbitration did not preclude the employee from a subsequent lawsuit. ${ }^{6}$ The basis for the Court's decision was twofold. First, the Court held that while arbitration was fine for contract rights (the just cause provision in the union contract), it was not appropriate for statutory rights (in this case, anti-discrimination law). ${ }^{7}$ Second, the Court held that union arbitration provisions were inappropriate for resolving discrimination lawsuits because the union, not the employee, "owned" the grievance, and because the union, by definition, was supposed to focus on the good of the whole, the individual case could get lost. ${ }^{8}$ Most lawyers and scholars took the holding of Gardner-Denver to mean that pre-dispute mandatory arbitration policies did not prevent employees from pursuing a statutory claim in court. This consensus lasted until Gilmer v. Interstate/Johnson Corp. in $1991 .{ }^{9}$

In Gilmer, the employee had to sign an arbitration agreement as a condition to accepting a position that involved working on the New York Stock Exchange (NYSE). ${ }^{10}$ The NYSE agreement provided that all disputes arising out of employment would be adjudicated before an arbitrator and thus precluded the employees from filing cases in court. ${ }^{11}$ After

Water, and Constructing a New Sink in the Process, 2 U. PA. J. LAB. \& EMP. L. 73, 133 (1999) [hereinafter Sherwyn et al., Saving the Baby].

2415 U.S. 36, 38-39 (1974).

3 Id. at 42 .

4 Id.

5 Id. at 43 .

6415 U.S. 36, 49 (1974).

$7 \mathrm{Id}$. at 53-54.

$8 \mathrm{Id}$. at 52,58 n. 19 .

9500 U.S. 20 (1991).

$10 I d$. at 23 .

$11 \mathrm{Id}$. 
two years of employment, the company fired Gilmer, who then filed an age discrimination case in federal court. ${ }^{12}$ The employer filed a motion to compel arbitration and the issue was once again ripe, but this time the result was different. ${ }^{13}$

The Gilmer Court enforced the motion to compel and distinguished Gilmer from the employee in Gardner-Denver because Gilmer's contract was an individual contract and not a union contract. ${ }^{14}$ The fact that Gilmer's case involved a statutory right did not affect the decision because there was Supreme Court precedent to enforce arbitration of statutory rights as long as the statute did not expressly prohibit arbitration. ${ }^{15}$ It must be noted that Gilmer does not prevent an employee from filing a claim with the Equal Employment Opportunity Commission or any other administrative agency and it cannot prevent that agency from filing a claim on behalf of the employee. ${ }^{16}$

Gilmer made two more arguments that the Court rejected. First, Gilmer argued that the arbitration was unfair because in some cases (1) there are no written opinions, (2) the employee does not get to choose the arbitrator, (3) damages are less than that provided in court, (4) discovery is limited, and (5) the employee's decision to sign the contract is not knowing and voluntary. ${ }^{17}$ Second, he argued that his employment contract was not covered by the Federal Arbitration Act (FAA) and, thus, there was no basis for enforcing the contract. ${ }^{18}$ The Court rejected the first three fairness issues, not because these "defects" would make a policy unfair and therefore unenforceable, but because the NYSE policies provided for written opinions, choice of arbitrator, and damages equal to those in court. ${ }^{19}$ The Court rejected the discovery issue because the point of arbitration is that it should be quicker and less expensive than litigation, so limited discovery was not only acceptable, it was part of the process. ${ }^{20}$ With regard to the "knowing and voluntary" contention, the Court held that a take it or leave it policy is effectively voluntary. ${ }^{21}$ The unequal bargaining power in this situation does not make signing the

12 Id. at $23-24$.

$13 I d$. at 24.

$14 I d$. at 33-34. After Gilmer it seemed that arbitrations in union contracts could not prevent litigation. This later changed in 14 Penn Plaza LLC v. Pyett, 556 U.S. 247, 247-48 (2009).
15500 U.S. 20, 34-35 (1991).
$16 \mathrm{Id}$. at $31-33$.
$17 \mathrm{Id}$. at 30-31.
$18 \mathrm{Id}$. at 26-27.
19 Id. at 30-31.
$20 \mathrm{Id}$.
21 Id. at 32-33. 
contract involuntary, since the employee could walk away from the employment offer. ${ }^{22}$

The second argument concerned the FAA. ${ }^{23}$ The FAA instructs courts to enforce arbitration agreements, but excludes employment contracts for "seamen, railroad employees, or any other class of workers engaged in foreign or interstate commerce." ${ }^{24}$ Gilmer argued that the term "commerce" in the FAA should be interpreted broadly and thus exclude all employment contracts. ${ }^{25}$ As one would expect, the employer argued for a narrow interpretation of the term commerce and contended that exclusion of employment contracts was limited to employees in the transportation industry. ${ }^{26}$ The Gilmer Court held that it did not have to rule on the definition of commerce because a contract between an employee of Interstate/Johnson and the NYSE was not an employment contract since the NYSE was not the employer. ${ }^{27}$ Since the contract was not an employment contract, it was not excluded from coverage under the FAA. ${ }^{28}$ Because very few industries have a governing body that requires employees to sign contracts in order to work, the Gilmer Court's FAA holding was extremely limited. Thus, after Gilmer there were two main issues: what constitutes a fair agreement and the effect of the FAA.

In the next twenty years, the courts defined both what is fair and the effect of the FAA. The effect of the FAA is easily described. In Circuit City v. Adams, ${ }^{29}$ the Supreme Court held that congressional intent behind the phrase "seamen, railroad employees, or any other class of workers engaged in foreign or interstate commerce" was limited to the transportation industry and that commerce did not have the widespread meaning that is ascribed to it today. ${ }^{30}$ Thus, any employer outside the transportation industry can implement an arbitration policy as long as it is fair.

With regard to fairness, most jurisdictions simply examine the substance of the policy and determine what is fair. The threshold rules from Gilmer (i.e., written opinions, statutory damages, choice of arbitrator, some discovery, and knowing and voluntary), the so-called "due process protocol," 31 and the standards set forth in Armendariz v. Foundation

22 Id.

23 Id. at 33.

$24 I d$. at $24-25,25$ n.2.

$25 I d$. at 25 n. 2 .

$26 \mathrm{Id}$. at 23.

27 Id.

28 Id. at 25 n. 2 .

29532 U.S. 105 (2001).

30 Id. at 119.

31 The American Arbitration Association's Due Process Protocol covers, among other things, the right of representation, the fees for representation, access to information, selection of arbitrators, and qualifications of arbitrators. See Am. Arbitration Ass'n, Employment 
Health Psychcare Services, Inc. ${ }^{32}$ created a template for determining fairness. Of course, different jurisdictions have slightly different standards. For example, some jurisdictions require mutuality, while others hold that the costs to the employee must not exceed those which would be charged by a court. ${ }^{33}$

In California, contracts are unenforceable if they are procedurally and substantively unconscionable. In Circuit City Stores, Inc. v. Adams (Adams III), ${ }^{34}$ the Ninth Circuit, applying California law, held that "take or leave it" clauses are procedurally unconscionable. ${ }^{35}$ Next, the court, still applying California law, held that the policy was substantively unconscionable because it limited damages and did not require mutuality. ${ }^{36}$ In other words, employees were required to arbitrate, but employers could litigate. ${ }^{37}$ The court then refused to enforce Circuit City's policy because it failed both tests. ${ }^{38}$ In Circuit City Stores, Inc. v. Ahmed, ${ }^{39}$ however, the Ninth Circuit held that an "opt-out" option (i.e., the employee was covered by the arbitration policy, but had thirty days to "optout") was not procedurally unconscionable and then enforced the same policy that it earlier had found substantively unconscionable. ${ }^{40}$ Thus, in California employers can have substantively unconscionable policies as long as there is an opt-out for employees.

In 14 Penn Plaza LLC v. Pyett, ${ }^{41}$ the issue before the Court was whether an arbitration agreement in a union contract prohibited an employee from filing an age discrimination case in federal court-a proposition that seemingly conflicted with Gardner-Denver. ${ }^{42}$ In upholding the arbitration agreement, the Court effectively, but not expressly, overturned Gardner-Denver by holding that arbitration clauses in collective bargaining agreements can prohibit litigation as long as the clause clearly and expressly states that the arbitration agreement prohibits the employ-

Due Process Protocol (1995), https://www.adr.org/cs/idcplg?IdcService=GET_ FILE\&dDocName=ADRSTAGE2025665\&RevisionSelectionMethod=latestReleased.

326 P.3d 669 (2000).

33 Id. at 692. But see Kepas v. eBay, 412 Fed. App'x 40, 47 (10th Cir. 2010) (holding that the employer solved the mutuality problem by exempting all issues relating to company's Employee Propriety Information and Inventions Agreement). Thus, employers could use the courts to pursue injunctions over trade secrets and employees could use the courts to protect their own inventions. The court noted this was a narrow exemption because the nature of the work led to inventions by employees. $I d$.

34279 F.3d 889 (9th Cir. 2002).

$35 \mathrm{Id}$. at 893.

$36 \mathrm{Id}$.

$37 \mathrm{Id}$.

$38 \mathrm{Id}$. at 896.

39283 F.3d 1198 (9th Cir. 2002).

40 Id. at 1198.

41556 U.S. 247 (2009).

42 Id. at 251. 
ees from pursuing their cases in court. ${ }^{43}$ Thus, for the last seven years, employers with experienced employment counsel have been able to draft policies that will ensure that their employment lawsuits will be resolved in arbitration, not litigation. In fact, prior to the spring of 2016, we could have stated that not only will arbitration agreements be enforceable, they also can preclude class action waivers. This conclusion is no longer valid because there is now a split in the circuits.

Below we address whether class action waivers should be enforceable or not. Prior to the spring of 2016 there was no question that such waivers were enforceable. Now, however, the enforceability of the class action waivers is an open question.

\section{B. Class Action Waivers}

In two cases, Mitsubishi Motors Corp. v. Soler Chrysler-Plymouth, Inc. ${ }^{44}$ and Amchem Prods., Inc. v. Windsor ${ }^{45}$ the Supreme Court held that arbitration does not deny a party a statutory right and that the use of class actions is a procedural, not a substantive right. Thus, absent legislation expressly prohibiting arbitration or class action waivers, the Court's precedent is clear: pre-dispute mandatory arbitration agreements with class action waivers are enforceable.

In In re D.R. Horton, however, the National Labor Relations Board (NLRB or Board) held that the National Labor Relations Act (NLRA) does, in fact, prohibit class action waivers. ${ }^{46}$ On appeal, however, the Fifth Circuit refused to enforce that part of the Board's decision. ${ }^{47}$ Similarly, the Eighth Circuit in Cellular Sales of Missouri, LLC v. National Labor Relations Board expressly rejected the Board's position. ${ }^{48}$ The Fifth and Eighth Circuits are in agreement with the Second Circuit in Sutherland v. Ernst \& Young, LLP, ${ }^{49}$ and seemingly with the Ninth Circuit in Richards v. Ernst \& Young, LLP, where the court rejected the NLRB's D.R Horton decision, but the rejection was not part of the holding, because the plaintiff did not bring up the NLRA argument until the appeal. ${ }^{50}$ In Lewis v. Epic Systems Corp., however, the Seventh Circuit

43 Id. at 248 .

44473 U.S. 614, 627 (1985).

45521 U.S. 591, 612-13 (1997).

46 See 357 N.L.R.B. 2277 (2012) (noting that D.R. Horton does not hold that pre-dispute mandatory arbitration agreements violate the NLRA, just that the class action waiver does).

47 See D.R. Horton, Inc. v. NLRB, 737 F.3d 344 (5th Cir. 2013).

48824 F.3d 772, 772 (8th Cir. 2016).

49 See 726 F.3d 290, 297 n.8 (2d Cir. 2013).

50734 F.3d 871, 873-74 (9th Cir. 2013) ("Alternatively, Ms. Richards urges that we may rely on the decision of the National Labor Relations Board ("NLRB") decision in D.R. Horton to affirm the district court's judgment. We decline to do so. Ms. Richards failed to raise the argument that her arbitration agreement with Ernst \& Young was unenforceable under the National Labor Relations Act ("NLRA") until after the parties had briefed, and the district 
adopted the Board's D.R. Horton ruling. ${ }^{51}$ Two months later, the Ninth Circuit, in Morris v. Ernst \& Young, followed the reasoning of the Epic case and denied enforcement of the plaintiffs' motion to dismiss. ${ }^{52}$ Thus, there is a split in the circuits.

There are several issues that factor into the respective class action waiver decisions, but as far as we are concerned, the question comes

court had denied, Ernst \& Young's motion to compel. "We apply a "general rule" against entertaining arguments on appeal that were not presented or developed before the district court.' We also note that the only court of appeals, and the overwhelming majority of the district courts, to have considered the issue have determined that they should not defer to the NLRB's decision in D.R. Horton because it conflicts with the explicit pronouncements of the Supreme Court concerning the policies undergirding the Federal Arbitration Act ("FAA") . . . .") (citing Peterson v. Highland Music, Inc., 140 F.3d 1313, 1321 (9th Cir. 1998)). Id. at 874 n.3 ("See, e.g., Owen v. Bristol Care, Inc., 702 F.3d 1050, 1055 (8th Cir. 2013) ("G]iven the absence of any "contrary congressional command" from the FLSA that a right to engage in class actions overrides the mandate of the FAA in favor of arbitration, we reject Owen's invitation to follow the NLRB's rationale in D.R. Horton . . . .' (quoting CompuCredit Corp. v. Greenwood, 132 S. Ct. 665, 669 (2012)); Delock v. Securitas Sec. Servs. USA, Inc., 883 F. Supp. 2d 784, 789 (E.D. Ark. 2012) ('The Court declines to endorse, however, the Board's application of the Federal Arbitration Act or its reading of the precedent applying that Act. The NLRA, as interpreted in Horton, conflicts with the FAA, as interpreted by the Supreme Court.') ... . .); id. at 874 ("Finally, the Supreme Court recently has reiterated that 'courts must rigorously enforce arbitration agreements according to their terms' and that this 'holds true for claims that allege a violation of a federal statute, unless the FAA's mandate has been overridden by a contrary congressional command.'”). Id. at 874 n. 3 (“.... Morvant v. P.F. Chang's China Bistro, Inc., 870 F. Supp. 2d 831, 845 (N.D. Cal. 2012) ('concluding that "Congress did not expressly provide that it was overriding any provision in the FAA when it enacted the NLRA or the Norris-LaGuardia Act" ") (internal quotation marks omitted)); Jasso v. Money Mart Express, Inc., 879 F. Supp. 2d 1038, 1049 (N.D. Cal. 2012) ('Because Congress did not expressly provide that it was overriding any provision in the FAA, the Court cannot read such a provision into the NLRA and is constrained by [AT\&T Mobility LLC v.] Concepcion [, 131 S. Ct. 1740 (2011),] to enforce the instant agreement according to its terms.'); LaVoice v. UBS Fin. Servs., Inc., No. 11 Civ. 2308 (BSJ) (JLC), 2012 WL 124590, at *6 (S.D.N.Y. Jan. 13, 2012) (holding that "this Court must read AT\&T Mobility as standing against any argument that an absolute right to collective action is consistent with the FAA's "overarching purpose" of "ensur[ing] the enforcement of arbitration agreements according to their terms so as to facilitate streamlined proceedings" and that, "[t]o the extent that LaVoice relies on . . . the recent decision of the [NLRB] in D.R. Horton, Inc. . . ., as authority to support a conflicting reading of AT\&T Mobility, this Court declines to follow th[at] decision[ ]" (quoting AT\&T Mobility, 131 S. Ct. at 1748)). But see Brown v. Citicorp Credit Servs., No. 1:12-cv-00062-BLW, 2013 WL 645942, at *3 (D. Idaho Feb. 21, 2013) (deferring to NLRB's decision in D.R. Horton under Chevron, U.S.A., Inc. v. Natural Res. Def. Council, Inc., 467 U.S. 837 (1984), as 'rational and consistent' with the NLRA, but failing to consider countervailing policies or deference with respect to the FAA); Herrington v. Waterstone Mortg. Corp., No. 11-cv-779-bbc, 2012 WL 1242318, at*6 (W.D. Wis. Mar. 16, 2012) (finding 'the Board's interpretation of the NLRA in D.R. Horton[ ] is reasonably defensible' and, therefore, 'applying it . . . to invalidate the collective action waiver in the arbitration agreement' (internal quotation marks omitted))"). Id. at 874 ("Congress,' however, 'did not expressly provide that it was overriding any provision in the FAA when it enacted the NLRA or the Norris-LaGuardia Act.'" (quoting Morvant v. P.F. Chang's China Bistro, Inc., 870 F. Supp. 2d 831, 845 (N.D. Cal. 2012))).

51823 F.3d 1147 (7th Cir. 2016).

52834 F.3d. 975 (9th Cir. 2016). 
down to whether filing a class action lawsuit is a substantive right protected by the NLRA. To answer this question, we need to examine the NLRA, ${ }^{53}$ the FAA, ${ }^{54}$ and Federal Rule of Civil Procedure 23 (Rule 23), ${ }^{55}$ which allows for class actions.

The NLRA provides that "[e]mployees shall have the right to selforganize, to form, join, or assist labor organizations, to bargain collectively through representatives for the purpose of collective bargaining or other mutual aid or protection." 56 The question is whether the term "other mutual aid or protection" creates a substantive right to file class actions. The FAA provides that any written contract "evidencing a transaction involving commerce to settle by arbitration a controversy thereafter arising out of such contract or transaction . . . shall be valid, irrevocable, and enforceable, save upon such grounds as exist at law or in equity for the revocation of such contract." 57 Rule 23 describes the process by which plaintiffs can be certified as a class when pursuing their legal claims. Thus, to hold that the NLRA prohibits class action waivers, one must conclude that the procedural right of Rule 23 is actually a substantive right under the NLRA and does not undermine the FAA.

First, we will examine the NLRA and Rule 23. There is no dispute that the use of Rule 23's class action procedures is a procedural, not a substantive, right. ${ }^{58}$ In Deposit Guaranty National Bank v. Roper, ${ }^{59}$ the Supreme Court stated that the right of a litigant to employ the class action procedures of Federal Rule of Civil Procedure 23, or the collective action procedures under the FLSA, ${ }^{60}$ "is a procedural right only, ancillary to the litigation of substantive claims." 61 Both the NLRB in D.R. Horton, and the Seventh Circuit in Epic, accept that Rule 23 is a procedural right, but contend that its use is a substantive right under the NLRA.

The Board, the Seventh Circuit, and the Ninth Circuit make similar arguments in holding that filing a class action is a substantive right under the NLRA. The Seventh Circuit stated that the "right to collective action in [S] ection 7 of the NLRA is not, however, merely a procedural one. It instead lies at the heart of the restructuring of the employer/employee

53 National Labor Relations Act, 29 U.S.C. $\S \S 151-169$ (2012).

54 Federal Arbitration Act, 9 U.S.C. $\S$ 1-14 (2012).

55 Fed. R. Civ. P. 23.

5629 U.S.C. $\S 157$ (2012).

579 U.S.C. $\$ 2$ (2012).

58 See Amchem Prods., Inc. v. Windsor, 521 U.S. 591, 612-13 (1997); see also Deposit Guar. Nat'l Bank. v. Roper, 445 U.S. 326, 332 (1980).

59 Roper, 445 U.S. at 332.

6029 U.S.C. $\S 216$ (b) (2012).

61 In re D.R. Horton, 357 N.L.R.B. 2277, 2278, 2286 (2012) (citing Roper, 445 U.S. at $332)$. 
relationships that Congress meant to achieve in the statute."62 Similarly, the Board in D.R. Horton stated that "Rule 23 may be a procedural rule, but the Section 7 right to act concertedly by invoking Rule 23, Section 216 (b), or other legal procedures is not." 63

There are a number of ways to attempt to get to the heart of this matter. First is the fact that the NLRA predates both Rule 23 and the FLSA. Can the NLRA create a substantive right from something that did not exist at the time of its passing? It seems the answer is a clear yes. If not, any type of electronic communication would fall outside the purview of the NLRA because it did not exist at the time. We could come up with numerous other examples that would make the chronological argument seem silly. Second, we should look to the NLRA and try to determine if class action should be considered a substantive right that is so absolute that it cannot be waived. As stated above, the Epic court stated that collective action is the heart of what Congress was attempting to achieve in the Act. ${ }^{64}$ It is obviously clear, however, that filing an FLSA class action does not facilitate forming, joining, or assisting labor organizations for the purpose of collective bargaining through representatives. Thus, to be covered by the Act, the class action must fit into the catchall: "other mutual aid or protection." Thus, the question is whether filing a class action is what Congress meant when it used this term and whether the term is absolute or should be part of a balancing act.

Of course, direct and actual congressional intent is impossible to reveal when neither the FLSA nor Rule 23 existed at the time of the passage of the NLRA. Furthermore, there is no direct evidence to support the contention that a congressional purpose of the Act was to allow employees greater access to litigation over issues that have nothing to do with collective bargaining. Thus, to support the holding in Epic, one would have to infer that Congress intended to protect all concerted activity, even if does not lead to collective bargaining and that the employee's rights trump all others. This is not the case. The NLRB has been "balancing the rights of employees and employers since its inception. The most famous and common balancing tests revolve around the employees' rights to organize on employer property and the employer's property rights." 65

On October 1, 2014, the Daily Labor Reports produced an analysis of the evolution of the balancing test between employees' Section 7 rights to organize and the employer's right to protect its property. Below

62 Lewis v. Epic Sys. Corp., 823 F.3d 1147, 1160 (7th Cir. 2016).

63 D.R. Horton, 357 N.L.R.B. at 2286.

64 See Epic, 823 F.3d at 1160.

65 Lechmere, Inc. v. NLRB, 502 U.S. 527 (1992); NLRB v. Babcock \& Wilcox Co., 351 U.S. 105 (1956). 
we provide this analysis to demonstrate how the courts have been balancing rights since at least 1945 .

In Republic Aviation Corp., $v$ NLRB, the Supreme Court weighed the employer's management rights and the need to maintain order and discipline in the workplace against the employees' rights under the Act. ${ }^{66}$ The Court held that when an employee is not on work time, his time is his own, and he can engage in union solicitation activity, even if he is on the employer's property. ${ }^{67}$ This balancing test was once again employed in NLRB v. Babcock \& Wilcox Co. ${ }^{68}$ In that case, nonemployee union organizers were distributing union literature in employer-owned parking lots. ${ }^{69}$ The Court overturned the Board, finding that the refusal of the employers to permit distribution of union literature by non-employee union organizers on company-owned parking lots did not unreasonably impede their employees' right to self-organization. ${ }^{70}$ The Court reasoned that the locations of both the working and living areas of the employees did not place the employees beyond the reach of reasonable efforts of the unions to communicate with them by other means. ${ }^{71}$ The Court reiterated that " $[t]$ he Act requires only that the employer refrain from interference, discrimination, restraint or coercion in the employees' exercise of their own rights. It does not require that the employer permit the use of its facilities for organization when other means are readily available." 72 In Lechmere, Inc. v. $N L R B$, the Court stated it was improper even to begin a balancing test with regard to Section 7 and private property rights unless "reasonable access to employees is infeasible."73

The Board later addressed off-duty employees' rights to organize.

In Tri-County Medical Center, 222 N.L.R.B. 1089, 91 LRRM 1323 (1976), the NLRB developed a threepart test to determine the validity of an employer's offduty access policy. The [B] oard found such policies to be lawful only if the policy: (1) limits access solely to the interior of the facility and other working areas; (2) is clearly disseminated to all employees; and (3) applies to off duty employees seeking access to the facility for any purpose and not just to those engaging in union activity.

The first prong of the test recognizes the employer's interest in controlling employee activity in

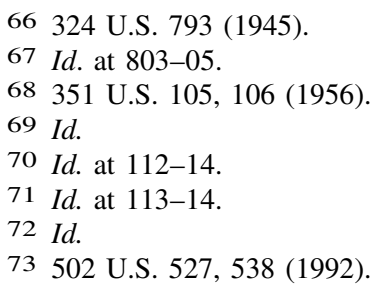


working areas because of its potential effects on production. The second prong balances the strength of the employer's legitimate interest. The board believes that unless the employer clearly tells its employees about the policy, the employer's interests will likely not outweigh the employee's. Finally, the third prong looks to the neutrality of the policy, as applied for any purpose. ${ }^{74}$

If organizing a union is not an absolute right, then clearly filing a class action is not an absolute right and therefore it makes sense to balance the employees' rights, the employers' rights, and in this case, the FAA.

As stated above, the FAA evidences federal policy to encourage arbitration as a method to resolve disputes. The court in D.R. Horton relied on the earlier decision AT\&T Mobility, LLC v. Concepcion to hold that barring class action waivers violates the FAA. ${ }^{75}$ In Concepcion, the Court analyzed the legality of a California statute prohibiting class action waivers. ${ }^{76}$ In finding that the statute violated the FAA, the Court held that eliminating class action waivers seriously undermined the company's arbitration policy and thus violated the FAA. ${ }^{77}$ The Court found that class-wide arbitrations sacrificed informality, the principle advantage of arbitration, and made "the process slower, more costly, and more likely to generate procedural morass than final judgment." 78 The Court then held that class wide arbitration "interferes with the fundamental attributes of arbitration and thus creates a scheme inconsistent with the FAA."79

The Board in D.R. Horton and the Epic court contend that eliminating the legality of the class action waiver under the NLRA does not interfere with an employer's dispute resolution policy. Thus, it does not violate the FAA because employers can still restrict all individual claims to arbitration, and the NLRB does not protect supervisors, casual employees, or confidential employees. Such a holding seemingly violates the express language of Concepcion. As the Horton court stated: "Regardless of whether employees resort to class procedures in an arbitral or in a judicial forum, employers would be discouraged from individual arbitration." 80

74 Adam Dougherty \& Jacquelyn Thompson, NLRB's Continuing Expansion of Off-Duty Access Rights, 190 Daily Lab. Rep. (BNA) (Oct. 1, 2014).

75 See D.R. Horton, Inc. v. NLRB, 737 F.3d 344, 359-62 (5th Cir. 2013); see also AT\&T Mobility, LLC v. Concepcion, 563 U.S. 333, 343 (2011).

76 Concepcion, 563 U.S. at 365-66.

77 Id. at 360 .

78 Id. at 348.

79 Id.

80 D.R. Horton, 737 F.3d at 359. 
Since we believe the right to file a class action is not an absolute right, we contend that the proper analysis is the historical balancing test. Courts should judge the effects of eliminating the class action waiver on employers, employees, and, we contend, society as a whole. Therefore we need to determine if (1) the Horton court was correct when it stated that eliminating class action waivers would undermine employers' motivations for implementing arbitration policies; (2) whether class action waiver truly harms employees; and (3) whether arbitration class action waivers harm or benefit society. Below, we discuss why employers implement arbitration policies and the effects of such policies on employees and society.

\section{Why Employers Implement Mandatory Arbitration Policies}

Detractors of mandatory arbitration imply that employers implement these policies to increase the probability of getting away with violating the law by making it harder for employees to bring claims and obtain redress for viable claims. While there are likely "evil" employers who do view arbitration as fulfilling such a purpose, we have studied numerous Alternative Dispute Resolution (ADR) employers who are motivated by a desire to decrease litigation costs and create an employee relations tool that will increase morale and reduce turnover. Indeed, one company we are aware of makes its policy optional and employees who agree to arbitration change their status from "at will" to "for cause."

Of course, reducing litigation costs can be perceived as a laudable goal or an effort to trample peoples' rights. In order to subscribe to the latter view, one must believe that employees do not file non-meritorious claims and that winning, regardless of whether it is right, is what motivates employers. While this could be true of some companies, those that we studied used their ADR policies as a method for correcting the unacceptable behavior. These companies are motivated by doing "the right thing." We are not saying that all of these companies are altruistic. They may or may not be. Regardless, they all determined that violating employee rights is bad business, and thus sought to resolve claims with the minimum amount of transaction costs.

Assuming that the employers implementing arbitration policies are seeking to "do the right thing," the question arises as to why class action waivers are so vital to the process. The employers we have studied regard their arbitration policies as an insurance type of risk-pooling endeavor. Sadly, the employers accept that, despite their best efforts, there will be legal violations. In addition, there will be false claims. Those that we have studied accept that they must settle the legitimate claims, but do not want to endure the costs of litigation on the non-meritorious claims. Moreover, they believe that their ADR policies, that almost always in- 
clude multi-step grievance procedures featuring mediation and other ADR processes, lead to better results for employees and employers. Eliminating class action waivers allows employees to opt out of the arbitration process when their case is ripe by attempting to turn their issue into a class-wide lawsuit. The costs required to defend the certification process undermine the entire model of the ADR policy, and make it untenable for employers.

\section{Do Class Action Waivers Harm Employees?}

The litany of publicized wage and hour class action settlements supports the view that class actions are an effective tool for employees who have been wronged by employers. ${ }^{81}$ A closer look, however, shows that class action settlements are, in fact, a boon for plaintiffs' lawyers that tend to provide little compensatory relief to employees. This fact begs two questions. First, are employees harmed by the lack of class actions, and second, are class actions the optimal way to address systemic legal violations?

Seasoned class action plaintiffs and defense lawyers know that there is a rhythm to employment class actions. The first priority for plaintiffs' lawyers is the potential for a large damage award against a deep-pocketed employer. Next, the parties battle for the certification for the class. At this point, the plaintiffs' lawyers have a large investment in the case. Defense lawyers are now in damage control mode. They work to knock out certain aspects of the claim to make the settlement numbers manageable. This posturing increases the plaintiffs' lawyers' investments in their cases, their costs, and thus, the amount of fees they need to recoup. ${ }^{82}$

When parties finally settle, the employer is comfortable with the damage award and the plaintiffs' lawyers sell the settlement to the employees. Are the employees justly compensated for their lost wages? Are they satisfied with their share of the award? These are empirical ques-

81 See generally Dr. Stephanie Plancich, Neil Fanaroff, \& Janeen McIntosh, Trends in Wage and Hour Settlements: 2015 Update, NERA ECONOMic Consulting (Jul. 14, 2015) (identifying "total wage and hour settlement payments of $\$ 445$ million in 2013, \$400 million in 2014, and \$39 million through the first three months of 2015" and signaling to employers that class action claims are an effective tool against employers' wrongdoing).

82 See Gregg A. Gilman \& David Sherwyn, Arbitration: A Positive Employment Tool and Potential Antidote to Class Actions, 2 Cornell Hospitality Labor \& Employment REPORT 1, 7 n.27 (2014), http://scholarship.sha.cornell.edu/cgi/viewcontent.cgi?article=1002\& context=cihlerpubs ("Indeed, at Georgetown Law School's Hospitality Law Conference (10/ 25/13 Washington D.C.) four seasoned management lawyers, all labor and employment department chairs, Gregg Gilman (Davis \& Gilbert) Carolyn Richmond (Fox Rothschild); David Ritter (Barnes \& Thornburg); Paul Wagner (Stokes, Wagner) stated that in their extensive collective experience, class action settlements almost exclusively revolved around plaintiffs' lawyers' fees, and the amount of money that the employees would recover bordered on inconsequential."). 
tions that have not been addressed. The contention that eliminating class actions is hurtful to employees is made without comparison to alternative ways in which class-wide relief may be sought. ${ }^{83}$

In a workplace where employees contracted away their right to file a class action, and a plaintiffs' lawyer invested the time and energy to discover a class-wide violation, ${ }^{84}$ the lawyer would file an arbitration demand and arbitrate the best claim first. The plaintiffs' lawyer would then continue to arbitrate the same claim over and over at the employer's expense. The first case would not entail the class certification issue, would not result in huge amounts of attorney time, and could be adjudicated instead of settled. The employee would not have to use her award to pay for the lawyers' time. Instead, the lawyer would have her hourly fee (as determined by the arbitrator and paid by the employer) and maybe a small percentage of the award.

Of course, the employer could, after losing the first case, continue to arbitrate this issue hundreds of times, but with genuine classes (i.e. where the plaintiffs' case features common issues of law and fact). However, this is inefficient. If the first arbitration yielded a pro-employee decision, the employer would not want to arbitrate the same claim again and again. This would increase the odds that the employer would, for the purposes of settlement, treat the group of putative employees as a class. Accordingly, subsequent arbitration cases would likely be settled by focusing exclusively on the employee's lost wages because the legal issue would be settled. The employer would pay what it owes, the employee would get what she deserves, and the plaintiffs' lawyers would lose a boondoggle. In short, reduced transactional costs associated with arbitration actually make repeat arbitration of class-wide violations more likely to yield a greater percentage of surplus funds for wronged employees, compared to attorneys and experts. Employees would thus be better off waiving their right to class actions in many cases, and using arbitration as a lever to gain de facto class status, but with a greater potential to yield available

83 The National Football League settled a lawsuit in which players sought redress for concussions and other physical and mental injuries. The media reported the settlement as acceptable to the players, who did not get health insurance, as a pragmatic decision because it could take years to actually litigate the case. See NFL Concussion Settlement, https://nflconcussionsettlement.com/ (last visited Dec. 10, 2016).

84 Admittedly, mandatory arbitration might reduce the attractiveness of the settle-ability of some class action claims, and thus reduce the likelihood that employees would be able to find representation. However, employees with individual claims would likely still be able to find representation (all else equal), and from there, the plaintiff-side attorney might discover the patterned nature of the claims. At this point, because the lawyer has sunk costs associated with the claim, it would be easier to bring repeated arbitration demands on behalf of other similarly situated employees. 
damages. ${ }^{85}$ Employers would likely regard a class action ban as an advantage only because the violation of the law and the true lost wages, not the costs of defense, would drive the settlement.

We therefore contend that class action waivers should be lawful if one were to utilize the classic NLRB balancing test because eliminating class action waivers hurts employers and does not truly help employees. Inherent in this argument is the idea that arbitration in general does not hurt employees. Moreover, as stated above, we believe that the balancing test should not be limited to just employers and employees. Instead, the effect of arbitration on society in general should be part of the balancing test. In the remainder of this Article, we examine the current system and assess whether it is the best use of government resources and the best method for resolving disputes. We contend it is not, and that not only should arbitration be lawful, it should be actively encouraged by the EEOC, the NLRB, other government agencies, and the law in general.

\section{What's Wrong With the Current System?}

Absent from most articles extolling the evils of arbitration is an indepth, and often any, discussion of the alternative to arbitration: the administrative agency and litigation process. As any employment litigator or litigant knows, this agency/litigation process is, at best, flawed, and at worst, an awful method for resolving employment disputes. It is slow, expensive, combative, formal, non-accommodating, and rarely results in a verdict. In fact, we contend that in discrimination cases, the system is so broken that justice is not even a consideration. Instead of justice, expedience and personal or organizational goals drive process and results.

\section{A. The EEOC Process}

As all discrimination law observers know, claimants cannot file complaints in federal court or state court without first going through an administrative agency. Since each state has its own procedures, it makes the most sense to examine the federal system: the Equal Employment Opportunity Commission (EEOC).

Filing with the EEOC is the first step in seeking redress for a violation of Title VII of the Civil Rights Act of 1964 (Title VII), ${ }^{86}$ the Age

85 This assumes that the likelihood of employees finding suitable representation is approximately the same or greater with a mandatory arbitration agreement in place in a given workplace. However, as noted in the previous footnote, it is possible that a mandatory arbitration agreement in place would reduce the likelihood of employees obtaining suitable representation. Given the greater share of damages awardable and reduced transaction costs, this remains an unaddressed empirical question. However, what is clear is that the definitive claim that banning class wide relief must make all employees worse off rings somewhat hollow given the parameters identified in this article.

8642 U.S.C. $\S \S 2000$ e to $2000 \mathrm{e}-17$ (2012). 
Discrimination in Employment Act (ADEA), ${ }^{87}$ and the Americans with Disabilities Act (ADA). ${ }^{88}$ The EEOC process is relatively straightforward. The Commission takes the claim, contacts the employer, seeks to resolves the claim, and if it cannot do so, investigates and then makes a finding as to whether there is probable cause. ${ }^{89}$ At that point, the claimant can file the case in federal court. ${ }^{90}$ If the case rises to the necessary level of importance for the Commission, it takes the case and assumes the role of the plaintiff. ${ }^{91}$ The problem is that the EEOC is overworked, under-funded and is dealing with a population that does not really understand the law. Thus, the system is, at best, inefficient and, at worst, features perverse incentives under which bad actors, on either side, can use it to circumvent justice. Below we explain the details of this system, the perverse incentives, and the lack of justice inherent in the resolutions.

Upon receiving a charge, the EEOC makes a categorical determination as to whether the case is an A, B, or C. ${ }^{92}$ According to the EEOC's national enforcement plan, the labels mean the following:

A. Cases involving violations of established anti-discrimination principles, whether on an individual or systemic basis, including Commissioner charge cases raising issues under the NEP, which by their nature could have a potential significant impact beyond the parties to the particular dispute.

1. Cases involving repeated and/or egregious discrimination, including harassment, or facially discriminatory policies.

2. Challenges to broad-based employment practices affecting many employees or applicants for employment, such as cases alleging patterns of discrimination in hiring, lay-offs, job mobility, including "glass-ceiling" cases, and/or pay, including claims under the Equal Pay Act.

B. Cases having the potential of promoting the development of law supporting the antidiscrimination purposes of the statutes enforced by the Commission.

8729 U.S.C. §§ 621-634 (2012).

8842 U.S.C. $\S \S 12101-12213$ (2012).

89 See Saving the Baby, supra note 1, at 80-81.

$90 \mathrm{Id}$. at 80.

91 Id.

92 Id. at 84-86; U.S. Equal Emp. Opportunity Comm'n, U.S. Equal Employment Opportunity Commission National Enforcement Plan (1997), https://www.eeoc.gov/ eeoc/plan/nep.cfm. 
1. Claims presenting unresolved issues of statutory interpretation under one or more of the statutes enforced by the Commission, as follows:

a. Claims presenting unresolved questions regarding the allocation of burdens in disparate treatment cases as set forth in St. Mary's Honor Center v. Hicks.

b. Claims presenting questions regarding the scope of liability under the statutes enforced by the Commission, including issues of employer liability in harassment cases and individual liability.

c. Claims of national origin discrimination involving language issues, including accent discrimination and restrictive language policies or practices.

d. Claims clarifying the Title VII duty to reasonably accommodate religious practices.

e. Claims raising unresolved questions under the Americans with Disabilities Act regarding the meaning of "reasonable accommodation" and the term "qualified individual with a disability," as well as the defenses of "undue hardship" and "direct threat."

f. Claims presenting questions regarding the interpretation of the prohibition of disparate impact discrimination under the Civil Rights Act of 1991, the Age Discrimination in Employment Act, and the Americans With Disabilities Act.

g. Claims based on the intersection of two or more prohibited bases of discrimination (e.g., discrimination against women of color, older women, or minority persons with disabilities).

h. Claims addressing the legality of agreements that mandate binding arbitration of employment discrimination disputes imposed as a condition of initial or continued employment.

i. Claims presenting unresolved issues regarding the provision of employee benefits, including claims arising under Title I of the Older Workers Benefits Protection Act, and the Americans With Disabilities Act.

j. Claims of comparable significance identified and approved in the Local Enforcement Plans. 
2. Cases involving legal issues where there is a conflict in the federal circuit courts on a Plan priority or in which the Commission is seeking Supreme Court resolution of such issue.

C. Cases involving the integrity or effectiveness of the Commission's enforcement process, particularly the investigation and conciliation of charges.

1. Cases involving allegations of retaliation against persons for participating in Commission proceedings or opposing unlawful employment discrimination, particularly cases where the scope of the statutory protection against retaliation is at issue.

2. Cases presenting challenges to Commission policy declarations, such as guidelines, regulations or policy guidance.

3. Cases protecting Commission access to information, including subpoena enforcement proceedings and proceedings to preserve or prevent the loss or destruction of evidence, except as set forth in paragraph 5 below.

4. Cases involving allegations of a material breach of an agreement to which the Commission was a party settling an earlier proceeding.

5. Cases involving alleged violations of the Commission's recordkeeping and reporting requirements where there is reason to believe that there may be another violation of statutes enforced by the Commission. ${ }^{93}$

The EEOC aggressively pursues many of its " $\mathrm{A}$ " cases and it is impossible to overestimate the effects of these cases. Indeed, the EEOC has litigated cases that have truly altered the employment discrimination landscape in the United States. We contend that the EEOC does an excellent job with the A cases it litigates, even when it does not prevail. Cases that define the law for employers and employees are valuable to society regardless of which side prevails. In fact, the EEOC's "greatest hits" of litigated cases is not just impressive, it is groundbreaking.

Since the enforcement plan went into effect, the EEOC has litigated, among others, the following "game-changing" cases:

93 U.S. Equal Emp. Opportunity Comm'n, U.S. Equal Employment Opportunity Commission National Enforcement Plan (1997), https://www.eeoc.gov/eeoc/plan/ nep.cfm. 


\section{B. EEOC Litigation}

\section{a. Racial Harassment}

- EEOC v. Patterson-UTI Drilling Company, LLC ${ }^{94}$ : The EEOC's Phoenix District Office entered into a $\$ 14.5$ million settlement and consent decree with Patterson-UTI, a Texas-based, multistate oil drilling company. The EEOC alleged that Patterson-UTI unlawfully maintained a nationwide practice of race-based discrimination, harassment, and retaliation. Unlawful practices included assigning minorities to the lowest level jobs, failing to train and promote minorities, and disciplining and demoting minority employees disproportionately. Those employees who opposed the harassing conduct were subject to retaliation such as discipline or discharge.

- EEOC v. Hillshire Brands Co. f/k/a Sara Lee Corp. ${ }^{95}$ : Hillshire Brands Company agreed to pay $\$ 4$ million dollars to seventyfour African-American former employees to settle a hostile work environment suit. African-American employees were subjected to racist slurs and graffiti and despite their complaints, the discrimination was not addressed.

- EEOC v. A.C. Widenhouse $e^{96}$ : Race harassment case on behalf of two victims. Jury verdict in January 2013 for $\$ 200,000$ in compensatory and punitive damages.

- EEOC v. AA Foundries ${ }^{97}$ : Race harassment on behalf of multiple victims. Jury verdict in September 2012 for $\$ 200,000$ in punitive damages.

94 Case No. 15-cv-00600-WYD-CBS (D. Colo. 2015); Press Release, U.S. Equal Emp. Opportunity Comm'n , Patterson-UTI Drilling to Pay \$14.5 Million to Settle Claims of Race/ National Origin Discrimination (Apr. 20, 2015), https://www.eeoc.gov/eeoc/newsroom/release/4-20-15.cfm.

95 Case No. 2:15-cv-1347 (E.D. Tex. 2015); Press Release, U.S. Equal Emp. Opportunity Comm'n, Hillshire Brands Company Pays \$4 Million to Settle Race Discrimination Suit (Dec. 22, 2015), https://www1.eeoc.gov/eeoc/newsroom/release/12-22-15.cfm.

96 No. 1:11-cv-498, 2013 WL 664230 (M.D. N.C. Feb. 22, 2013), aff'd, 576 Fed. App'x 227 (4th Cir. 2014); Press Release, U.S. Equal Emp. Opportunity Comm'n, Jury Awards $\$ 200,000$ in Damages Against A.C. Widenhouse in EEOC Race Harassment Suit (Feb. 1, 2013), https://www.eeoc.gov/eeoc/newsroom/release/2-1-13.cfm.

97 No. 5:11-cv-792 (W.D. Tex. 2011); Press Release, U.S. Equal Emp. Opportunity Comm'n, Court Orders AA Foundries to Take Extensive Measures to Prevent Racial Harassment (Oct. 12, 2012), https://www.eeoc.gov/eeoc/newsroom/release/10-12-12.cfm. 
b. Disparate Impact Cases

- EEOC v. BMW Manufacturing Co., LLC 98 : Settlement of $\$ 1.6$ million in race case challenging disparate impact of criminal conviction policy applied to long-term employees of contractor.

- EEOC v. Pepsi ${ }^{99}$ : Public conciliation for $\$ 3$ million for more than 300 African Americans adversely affected by criminal background check policy.

- EEOC v. Kaplan ${ }^{100}$ : Appellate court affirmed grant of summary judgment to employer dismissing credit screen policy and excluding EEOC expert witness on disparate impact.

- EEOC v. Freeman ${ }^{101}$ : Appellate court affirmed grant of summary judgment to employer in nationwide race discrimination case challenging disparate impact of felony conviction screens.

- EEOC v. Dollar General102: Nationwide race discrimination case challenging disparate impact of criminal background check policy for all positions.

- EEOC v. Crothall 103: The District court ruled employer is obligated under Title VII of the Civil Rights Act of 1964 to maintain records showing adverse impact of selection procedures, that the EEOC had the legal authority to issue the UGESP regulation that required recordkeeping, and that compliance with the EEOC's rule was mandatory and not "permissive."

c. ADA Accommodations

- EEOC v. LHC Group, Inc. d/b/a Gulf Coast Homecare ${ }^{104}$ : The Fifth Circuit affirmed, in part, the lower court's granting of summary judgment against the EEOC. Clarifying the long-standing circuit split on proving a prima facie case under the ADA, the Fifth Circuit held that an employee must show "he was subject to an adverse employment decision on account of his disabil-

98 Press Release, U.S. Equal Emp. Opportunity Comm’n, BMW to Pay \$1.6 Million and Offer Jobs to Settle Federal Race Discrimination Lawsuit (Sept. 8, 2015), https:// www.eeoc.gov/eeoc/newsroom/release/9-8-15.cfm.

99 Press Release, U.S. Equal Emp. Opportunity Comm'n, Pepsi to Pay \$3.13 Million and Made Major Policy Changes to Resolve EEOC Finding of Nationwide Hiring Discrimination Against African Americans (Jan. 11, 2012), https://www.eeoc.gov/eeoc/newsroom/release/111-12a.cfm.

100748 F.3d 749 (6th Cir. 2014).

101778 F.3d 463 (4th Cir. 2015).

102 EEOC v. DolGenCorp, LLC, No. 13-cv-04307, 2015 U.S. Dist. LEXIS 80140, at *1-12 (N.D. Ill. June 19, 2015).

103 EEOC v. Crothall Servs. Grp., No. 15-3812, 2016 U.S. Dist. LEXIS 83520, at *1-21 (E.D. Pa. June 28, 2016).

104773 F. 3d 688 (5th Cir. 2014) 
ity". ${ }^{105}$ The court remanded to resolve the disputed issues of material fact. ${ }^{106}$

- EEOC v. Ford Motor Co. ${ }^{107}$ : In an 8-5 decision, the Sixth Circuit, sitting en banc, vacated the panel's decision, and granted summary judgment for Ford. The court held that as a matter of law, the charging party, a resale buyer, was not qualified for her job due to unpredictable absences caused by her disability. The Court stated that regular in-person attendance was an essential function of most positions, and that telecommuting, as proposed in this case, was not a reasonable accommodation. ${ }^{108}$

- EEOC v. United Airlines ${ }^{109}$ : Effectively sitting en banc, the court reversed prior Seventh Circuit precedent and held that "best qualified" policies do not trump the ADA's reassignmentas-reasonable-accommodation obligation.

- EEOC v. Old Dominion Freight Line, Inc. ${ }^{110}$ : Judge held that Defendant's "no-return policy" violated the ADA as a matter of law and amounted to a denial of reasonable accommodation to the Charging Party. Jury verdict for $\$ 119,612$ in back pay. ${ }^{111}$

- EEOC v. Supervalu, Inc. ${ }^{112}$ : Court order requiring the company to cover such costs arising in a contempt proceeding brought against it for violations of a previously agreed upon consent decree resolving prior EEOC litigation against the company under the Americans with Disabilities Act (ADA), in which the agency charged that the company routinely failed to provide reasonable accommodations to employees seeking to return to work from a disability leave. ${ }^{113}$ Contempt action recently settled. ${ }^{114}$

- EEOC v. UPS ${ }^{115}$ : Court denied UPS's motion to dismiss, finding that the $100 \%$ return-to-work policy could be a job qualification under the ADA.

105 Id. at 697.

106 Id.

107752 F. 3d 634 (6th Cir. 2014) (en banc).

108 Id.

109693 F.3d 760 (7th Cir. 2012), cert. denied, 133 S. Ct. 2734 (2013).

110 No. 11-2153, 2013 WL 3230670 (W.D. Ark. 2013).

111 Press Release, U.S. Equal Emp. Opportunity Comm'n, Jury in EEOC Suit Says Old Dominion Freight Line Must Pay Former Driver \$119,612 for Disability Bias (Jan. 16, 15), https://www.eeoc.gov/eeoc/newsroom/release/1-16-15.cfm.

112 No. 09 C 5637, 2014 WL 6791853, at*1 (N.D. Ill. 2014).

113 Press Release, U.S. Equal Emp. Opportunity Comm'n, Supervalu/Jewel-Osco To Pay \$3.2 Million Under Consent Decree For Disability Bias (Jan. 5, 2011), https://www.eeoc.gov/ eeoc/newsroom/release/1-5-11a.cfm.

$114 I d$.

115 EEOC v. UPS, No. 09 C 5291, 2014 WL 538577, at *1, 4-5 (N.D. Ill. 2014). 
- EEOC v. Creative Networks ${ }^{116:}$ Court denied the company's motion for partial summary judgment, finding a genuine issue of material fact as to whether the company maintained a rigid policy of refusing to provide an ASL interpreter at orientation and training for deaf and hearing-impaired employees.

\section{d. Preserving Access to the Legal System}

- EEOC v. Cognis Corp. ${ }^{117}$ : Summary judgment for EEOC was granted in part, and denied in part, questioning whether a last chance agreement dissuaded employees from filing of an EEOC charge.

- EEOC v. Evans Fruit ${ }^{118}$ : EEOC obtained preliminary injunction prohibiting retaliation.

- EEOC v. New Breed Logistics ${ }^{119}$ : The Sixth Circuit upheld a jury verdict for the EEOC against New Breed Logistics. The jury awarded more than $\$ 1.5$ million to three female employees after finding that they were sexually harassed by a New Breed supervisor and retaliated against after they objected to his sexual advances. Additionally, the jury found that a male employee, who verbally opposed the harassment and supported the women's complaints, was also retaliated against. The Sixth Circuit's opinion clarified the scope of protected activity under the opposition clause of Title VII's retaliation provision. The Court, in a case of first impression, held that the "opposition clause" of Title VII has an "expansive definition" and courts should give "great deference" to the EEOC's interpretation of opposing conduct.

\section{e. EEOC and Sex Hiring Discrimination}

- EEOC v. Mavis Discount Tire ${ }^{120}$ : EEOC alleged Mavis Discount Tire refused to hire women for a wide variety of positions despite some applicants' superior qualifications and thus engaged in a pattern or practice of sex discrimination. Since at least 2008, only one woman was employed in any of these positions out of approximately 800 employees. Out of 1,300 hires made between 2008-2010 for those positions, not one was female. Additionally, despite Mavis's alleged failure to maintain applications-itself a

116912 F. Supp. 2d 828, 844, 847 (D. Ariz. 2012).

117 10-CV-2182, 2012 WL 1893725, at *1, 14 (C.D. Ill. 2012).

118 No. CV-10-3033-LRS (E.D. Wash. 2010) (order granting application for temporary restraining order).

119783 F. 3d 1057 (6th Cir. 2015).

120 Complaint, EEOC v. Mavis Discount Tire, Inc., No.112-cv-00741-JGK (S.D.N.Y. 2012). 
separate violation of federal law-those applications available indicated that women with superior credentials and experience were rejected while less qualified men were hired. The case was settled for $\$ 2.1$ million, to be divided among forty-six aggrieved women. ${ }^{121}$

- EEOC v. New Prime, Inc. ${ }^{122}$ : EEOC alleged that New Prime, Inc. failed to hire women for trucking positions. Court granted summary judgment in favor of EEOC finding Defendant engaged in a pattern or practice of discrimination. The case settled for \$3.1 million in damages and extensive injunctive relief, including job offers to women who were denied hire. ${ }^{123}$

- EEOC v. Presrite Corp. ${ }^{124}$ : The EEOC alleged Presrite failed to hire women for metal forging jobs. The case settled for $\$ 700,000$ and non-monetary relief including forty priority hires, and revised hiring policies. ${ }^{125}$

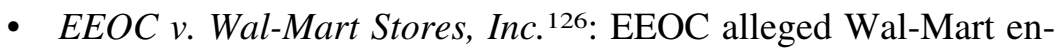
gaged in systemic failure to hire women for warehouse positions. Settled for $\$ 11.7$ million and broad non-monetary relief, including validation of interview questions and more than 50 positions for eligible claimants.

- EEOC v. Unit Drilling Company ${ }^{127}$ : EEOC alleged that Unit Drilling refused to hire any women nationwide on its oil rigs, and rejected female applicants testified that they were told by Unit employees that the company did not hire women because it only had "man camps," that women were "too pretty" and that their presence would "distract the men." Settled for $\$ 400,000$ to five women and extensive injunctive including change of its policies, provide training against sex discrimination, post anti-discrimination notices, and provide detailed hiring information to the EEOC, which will monitor Unit Drilling's compliance with the decree.

121 Press Release, U.S. Equal Emp. Opportunity Comm'n, Mavis Discount Tire to Pay \$2.1 Million to Settle EEOC Class Sex Discrimination Lawsuit (Mar. 25, 2016), https:// www.eeoc.gov/eeoc/newsroom/release/3-25-16.cfm.

12242 F. Supp. 3d 1201 (W.D. Mo. 2014).

123 Press Release, U.S. Equal Emp. Opportunity Comm'n, Prime, Inc. to Pay Over \$3 Million After Court Ruled It Used Discriminatory Hiring Practices (May 31, 2016), https:// www.eeoc.gov/eeoc/newsroom/release/5-31-16a.cfm.

124 Consent Decree, EEOC v. Presrite Corp., No. 11-cv-260 (N.D. Ohio 2011).

125 See EEOC, Resolutions: Selected List of EEOC Systemic Hiring Resolutions AND FiLings Since 2005 (Apr. 18, 2012).

126 Consent Decree, EEOC v. Wal-Mart Stores, Inc., No. 01-cv-339-KKC (E.D. Ky. 2001).

127 Consent Decree, EEOC v. Unit Drilling Co., No. 13-cv-00147-TCK-PJC (D. Okla. 2015). 
f. EEOC \& Discrimination Against Immigrant, Migrant, and Other Vulnerable Workers

- EEOC v. Moreno Farms, Inc. ${ }^{128}$ : A federal jury returned a unanimous verdict awarding a total of $\$ 17,425,000$ to five former female employees of Moreno Farms, Inc., a produce growing and packing operation in Felda, Florida, who suffered sexual harassment and retaliation.

- Chellen v. John Pickle Co. ${ }^{129}$ : Class, race, and national origin case alleging oil industry parts manufacturer subjected East Indian workers to discriminatory pay and working conditions. The court awarded \$1.24 million.

- David v. Signal International ${ }^{130}$ : Signal International, a Alabama ship building and repair company used the $\mathrm{H}-2 \mathrm{~B}$ guest worker program to recruit workers in the wake of hurricanes Katrina and Rita. Guest workers from India were subjected to a pattern or practice of race and national origin discrimination, including unfavorable working conditions and forcing workers to pay to live in overcrowded and unsanitary camps under guard. After the EEOC brought suit, Signal International settled for $\$ 5$ million dollars and issued a statement acknowledging wrongdoing and apologizing. ${ }^{131}$

- EEOC v. Vail Run Resort Community Association132: Vail Run and its management company, Global Hospitality Resorts, Inc., will pay $\$ 1,020,000$ as part of the settlement of a sexual harassment, national origin discrimination and retaliation lawsuit. The EEOC claimed the defendants violated federal law by allowing a male housekeeping manager to sexually harass Mexican female employees, which included propositions, groping, and attempted rape. The EEOC asserted the manager targeted Mexican immigrants who were particularly vulnerable, threatening them with job loss and deportation, and the defendants retaliated against men and women who complained about the harassment to management and the owner with discipline and discharge.

128 See Press Release, U.S. Equal Emp. Opportunity Comm'n, EEOC Wins Jury Verdict of Over \$17 Million for Victims of Sexual Harassment and Retaliation at Moreno Farms (Sep. 10, 2015), https://www1.eeoc.gov//eeoc/newsroom/release/9-10-15.cfm?renderforprint=1.

129 Chellen v. John Pickle Co., Inc., 446 F. Supp. 2d 1247 (N.D. Okla. 2006).

130 David v. Signal Int'l, LLC, No. 12-557 (E.D. La. Dec. 4, 2013) (order granting motion for entry of discovery plan and case management order).

131 Press Release, U.S. Equal Emp. Opportunity Comm'n, Signal International, LLC To Pay $\$ 5$ Million To Settle EEOC Race, National Origin Lawsuit (Dec. 18, 2015), https:// www.eeoc.gov/eeoc/newsroom/release/12-18-15.cfm.

132 Consent Decree, EEOC v. Vail Run Resort Cmty. Ass'n, Inc. et al., No. 15-CV01592-RPM-KMT (D. Colo. 2016). 
- EEOC v. Global Horizons, Inc. ${ }^{133}$ : National origin and race harassment case involving Thai farm workers. The case settled in November 2013 for \$1.2 million and innovative, comprehensive equitable relief.

\section{g. The EEOC and LBGT Coverage}

- EEOC v. Maritime Autowash, Inc. ${ }^{134}$ : Maritime Autowash did not produce information related to the EEOC's investigation of a charge of alleging national origin and retaliation. Maritime refused to fully comply with the subpoena, claiming that Title VII may not apply to the plaintiff as an undocumented person. The district court agreed and dismissed EEOC subpoena enforcement action. The Fourth Circuit overturned the district court and remanded with instructions to enforce EEOC subpoena.

- Cazorla v. Koch Foods of Mississippi ${ }^{135}$ : Pattern or practice hostile work environment based on sex, race and/or national origin and retaliation against a class of female and male Hispanic employees in a poultry processing plant.

- Macy v. Holder 136: The Commission ruled that employment discrimination against employees because they are transgender, because of their gender identity, and/or because they have transitioned (or intend to transition) is discrimination because on sex, and thus violates Title VII. ${ }^{137}$

- Lusardi v. McHugh ${ }^{138}$ : The EEOC issued a ruling that the Department of the Army discriminated against a transgender employee who during her employment transitioned from presenting as a man, to presenting as a woman, consistent with her gender identity. The EEOC found that the Department of the Army unlawfully discriminated by conditioning her access to the designated, common female restroom used by all other female employees on the completion of her gender reassignment surgery and by intentionally failing to address her by feminine pronouns. ${ }^{139}$

1337 F. Supp. 3d 1053 (D. Haw. 2014); Press Release, U.S. Equal Emp. Opportunity Comm'n, Del Monte Fresh Produce Agrees to Settle EEOC Farmworker National Origin Lawsuit, https://www.eeoc.gov/eeoc/newsroom/release/11-18-13a.cfm.

134 EEOC v. Mar. Autowash, Inc., 820 F.3d 662 (4th Cir. 2016).

135 Cazorla v. Koch Foods of Miss., L.L.C., No. 15-60562, 2016 U.S. App. Bloomberg Law 318550 (5th Cir. 2016).

136 Macy v. Holder, EEOC Appeal No. 0120120821 (eResolution Apr. 20, 2012), https:// www.eeoc.gov/decisions/0120120821 Macy v DOJ ATF.txt

137 Id.

138 Lusardi v. McHugh, EEOC Appeal No. 0120133395 (Apr. 1, 2015).

139 Id. 
- Baldwin v. Department of Transportation ${ }^{140}$ : Baldwin alleged that the Federal Aviation Agency (FAA) discriminated against him on the basis of his sexual orientation: he alleged that his manager made disparaging comments to him and others about his sexual orientation, and that he was not promoted to a permanent Front Line Manager position at the Miami airport's Air Traffic Control Tower because he is gay. The court held that discrimination on the basis of sexual orientation included in the prohibition against sex discrimination under Title VII of the Civil Rights Act of 1964. Allegations of discrimination on the basis of sexual orientation always and necessarily state claims of discrimination on the basis of sex. In other words, if an employee is discriminated against because s/he is gay, the employee will be able to show that the discrimination s/he experienced was sex discrimination. This is because it is impossible to consider someone's sexual orientation without considering their sex and the sex of the person(s) with whom the employee is romantically involved; and/or because the discrimination is based on a belief that men should only be attracted to women and women to men, which is a fundamental sex stereotype, norm, or expectation.

- EEOC v. Lakeland Eye Clinic ${ }^{141}$ : The EEOC recently filed this case on behalf of transgender charging parties in Florida. In Lakeland Eye, the theory of coverage was based on Glenn $v$. Brumby. ${ }^{142}$ On April 9, 2015, the EEOC entered into a historic $\$ 150,000$ settlement and consent decree with Lakeland Eye Clinic. Additionally, Lakeland agreed to implement a new gender discrimination policy and provide training to management and employees regarding transgender/gender stereotype discrimination.

- EEOC v. Deluxe Financial Services, Inc. ${ }^{143}$ : The EEOC alleges Charging Party had performed her duties satisfactorily in the company's Phoenix offices throughout a lengthy tenure there. However, after she began to present at work as a woman and informed her supervisors that she was transgender, Deluxe re-

140 Baldwin v. Dep't of Transp., EEOC Appeal No. 0120133080 (eResolution July 15, 2015), https://www.eeoc.gov/decisions/0120133080.pdf.

141 Consent Decree at 4, EEOC v. Lakeland Eye Clinic, No. 8:14-cv-2421-T35 AEP (M.D. Fla. Mar. 26, 2015); EEOC, FAct Sheet: Recent EEOC Litigation Regarding Title VII \& LGBT-Related Discrimination (July 8, 2016), https://www1.eeoc.gov//eeoc/litigation/selected/lgbt_facts.cfm?renderforprint=1

142663 F.3d 1312 (11th Cir. 2011) (considering claim under $\S 1983$, the court stated that "discrimination against a transgender individual because of her gender-nonconformity is sex discrimination, whether it's described as being on the basis of sex or gender").

143 No. 15-cv-02646 (D. Minn. 2015). 
fused to let her use the women's restroom. Supervisors and coworkers subjected the charging employee to a hostile work environment, including hurtful epithets and intentionally using the incorrect gender pronouns in reference to her.

- EEOC v. Pallet Companies, Inc. ${ }^{144}$ : The EEOC sued IFCO, a provider of reusable plastic containers, alleging that it discriminated against Yolanda Boone on the basis of sex by terminating her for complaining about harassment. The EEOC alleged that Boone, a lesbian woman, was harassed because of her sexual orientation and/or her non-conformity with the employer's gender-based expectations, preferences, or stereotypes in violation of Title VII. According to the EEOC's lawsuit, Boone's supervisor harassed Boone by repeatedly making comments, sometimes accompanied by sexually suggestive gestures, about her sexual orientation and nonconformity with stereotypical female gender norms. A few days after Boone complained to management and called IFCO's employee hotline to complain, IFCO terminated her employment in retaliation. In addition to monetary relief of $\$ 202,200$, the consent decree enjoins IFCO from engaging in sex discrimination or retaliation in the future. Additionally, the decree requires, inter alia, IFCO to retain an expert on sexual orientation, gender identity, and transgender training to assist in developing a training program for IFCO's staff on LGBT workplace issues.

- EEOC v. Scott Medical Health Center ${ }^{145}$ : The EEOC alleged that a gay male employee was subjected to harassment because of his sexual orientation in violation of Title VII. The employee subsequently quit after enduring weeks of offensive comments from his supervisor.

- Burrows v. College of Central Florida ${ }^{146}$ : EEOC argued, as amicus, that sexual orientation discrimination is covered under Title VII because of the prohibitions against discrimination based on sex stereotypes, association and gender.

- Evans v. Georgia Regional Hospital, Inc. ${ }^{147}$ : EEOC argued, as amicus, that sexual orientation discrimination is covered under Title VII because of the prohibitions against discrimination

144 Consent Decree at 3-4, EEOC v. Pallet Cos., No. 1:16-cv-00595-CCB (D. Md. June 28, 2016).

145 Complaint, EEOC v. Scott Med. Health Ctr., No. 2:16-cv-00225-CB (W.D. Pa. Mar. 1, 2016).

146 Brief for EEOC as Amicus Curiae Supporting Appellant, Burrows v. Coll. of Cent. Fla., No. 15-14554 (11th Cir. 2016).

147 Brief for EEOC as Amicus Curiae Supporting Appellant, Evans v. Georgia Reg'l Hosp., No. 15-14554 (11th Cir. 2016). 
based on sex stereotypes, association, and gender. In addition, EEOC argues retaliation is unlawful if the employee reasonably believes unlawful activities occurred and, in this case, the plaintiff's belief was objectively reasonable.

- Christiansen v. Omnicom Group, Inc. ${ }^{148}$ : The EEOC filed an amicus curie brief in support of Christiansen, arguing that sexual orientation discrimination is cognizable as sex discrimination under Title VII. EEOC argued that the Second Circuit should reconsider its Simonton v. Runyon decision for two reasons: the legal underpinnings for the decision have shifted, and the rule that Title VII does not prohibit discrimination based on sexual orientation is outdated.

- EEOC v. R.G. \& G.R. Harris Funeral Homes Inc. ${ }^{149}$ : The EEOC alleges that defendant discriminated based on sex by firing a Garden City, Michigan, funeral director/embalmer because she is transgender, because she was transitioning from male to female, and/or because she did not conform to the employer's gender-based expectations, preferences, or stereotypes. EEOC alleges the charging party had always performed satisfactorily. However, after working at the defendant for about six years, she gave Harris a letter explaining she was undergoing a gender transition from male to female and would soon start to present in appropriate business attire at work. EEOC contends that two weeks later, Harris's owner fired her, telling her what was "proposing to do" was unacceptable. The Commission recently survived defendant's motion to dismiss.

- Broussard v. First Tower Loan, LLC ${ }^{150}$ : Broussard and the EEOC, as intervenor, allege that Mississippi-based First Tower Loan, LLC violated federal law by firing a Lake Charles, Louisiana, manager-trainee because he is transgender, and/or because he did not conform to the employer's gender-based expectations, preferences or stereotypes. EEOC is seeking injunctive relief prohibiting First Tower Loan from engaging in unlawful sex discrimination in the future, as well as lost wages, compensatory and punitive damages for Broussard, and other relief the court deems proper. The case was stayed for arbitration.

148 Brief for EEOC as Amicus Curiae Supporting Appellant, Anonymous v. Christiansen, No. 16-748 (2nd Cir. 2016).

149 Complaint, EEOC v. R.G. \& G.R. Harris Funeral Homes, Inc., No. 2:14-cv-13710SFC-DRG (E.D. Mich. filed Sept. 25, 2014).

150 Complaint, Broussard v. First Tower Loan, LLC, No. 2:15-cv-01161-CJB-SS (E.D. Pa. 2015). 
h. EEOC and religious discrimination

- EEOC v. Abercrombie and Fitch"151: "Whether an employer can be liable under Title VII of the Civil Rights Act of 1964 for refusing to hire an applicant or discharging an employee based on a 'religious observance and practice' only if the employer has actual knowledge that a religious accommodation was required and the employer's actual knowledge resulted from direct, explicit notice from the applicant or employee."152 A divided panel reversed summary judgment for the EEOC and ordered the dismissal of the case in a case involving the denial of job to Muslim applicant with hijab because the charging party to did not put the company on sufficient notice of her need for an accommodation. ${ }^{153}$ Nine amicus briefs were filed in support of EEOC by various organizations including Beckett Fund, a coalition of Orthodox Jewish groups, Seventh Day Adventists and other religious groups, CAIR, and Lambda Legal. ${ }^{154}$ Three briefs were filed in support of Abercrombie, including by US Chamber of Commerce and EEAC. ${ }^{155}$

- EEOC v. Consol Energy, Inc. \& Consolidation Coal Co. ${ }^{156}$ : Defendant installed a time and attendance biometric hand scanner to track time and attendance. EEOC alleged the employee repeatedly told management officials that submitting to a biometric hand scanner violated his sincerely held religious beliefs as an Evangelical Christian. The employee was forced to retire because the employer refused to accommodate his religious beliefs. The jury returned a verdict of $\$ 150,000$ in compensatory damages and the district judge subsequently determined that the defendant must pay an additional $\$ 436,860$ to the employee for back pay and front pay.

- EEOC v. Fries Restaurant Management, LLC d/b/a Burger King 157: Despite being told during job interview that she could wear a skirt, in adherence with her Pentecostal beliefs, applicant

151135 S. Ct. 2028 (2015).

152 Petition for Writ of Certiorari, EEOC v. Abercrombie \& Fitch Stores, Inc., No. 14-86 (U.S. July 25, 2014).

153 Id. at 8.

154 Docket, EEOC v. Abercrombie \& Fitch Stores, Inc., No. 14-86 (U.S. July 25, 2014).

155 Id.

156 No. 13-cv-00215 FPS (N.D. W. Va. 2015).

157 Press Release, U.S. Equal Emp. Opportunity Comm'n, Burger King Franchisee Settles EEOC Discrimination Lawsuit (Jan. 23, 2013), https://www1.eeoc.gov//eeoc/newsroom/re lease/1-23-13.cfm?renderforprint=1. 
was sent home during orientation and never brought back to work. The case was settled for $\$ 25,000.158$

- EEOC v. AutoZone, Inc. ${ }^{159}$ : Suit alleged the employer subjected employee, who had converted to the Sikh religion, to harassment and refused to accommodate his religious need to wear a turban. Resolved in nationwide consent decree in March 2012 for $\$ 75,000$ and injunctive relief.

\section{EEOC Investigations}

In addition to litigation, the EEOC has dedicated resources to preventing employment discrimination through education and outreach by working with new and small businesses and employees. For example, in 2015 the EEOC conducted over 3700 no-cost outreach events and reached 336,855 individuals. The EEOC no-cost outreach events were attended by 23,790 small business representatives and the EEOC entered into 235 partnerships with groups that represent small businesses. ${ }^{160}$ These facts simply scratch the service of all the positive work the EEOC does with regard to litigation and outreach efforts. It is clear that the EEOC is an effective litigator and educator-the problem is that the EEOC simply does not have the resources to resolve "garden variety" discrimination claims. Thus, these cases could be better served with another system.

The EEOC system is not an exact science and the different offices are free to create their own standards. ${ }^{161}$ Still, there is enough in common to report a fairly clear understanding of the how the system works. ${ }^{162}$ The intake officers provide three services: they begin the file, counsel the employee, and label the case. ${ }^{163}$ The first task is obvious. The counseling occurs when the charging party is alleging treatment that does not violate the law. ${ }^{164}$ For example, a party may allege "My supervisor treats me poorly because I'm a Mets fan and she likes the Yankees." While one of the authors may argue that being a Mets fan should be a protected class,

158 Press Release, U.S. Equal Emp. Opportunity Comm'n, Burger King Franchisee Settles EEOC Discrimination Lawsuit (Jan. 23, 2013), https://www1.eeoc.gov//eeoc/newsroom/re lease/1-23-13.cfm?renderforprint=1.

159 No. 10-cv-11648-WGY (E.D. Mass. 2012); Press Release, U.S. Equal Emp. Opportunity Comm'n, AutoZone to Pay $\$ 75,000$ to Settle EEOC Religious Discrimination Lawsuit (Mar. 30, 2012), https://www1.eeoc.gov//eeoc/newsroom/release/3-30-12a.cfm?renderfor print $=1$.

160 See U.S. Equal Emp. Opportunity Comm'n, Fiscal Year 2015 Performance and ACCOUntABILITY RePORT (2015), http://www.eeoc.gov/eeoc/plan/upload/2015par.pdf.

161 Interview with Patrick David Lopez, Gen. Counsel, U.S. Equal Emp't Opportunity Comm'n, in Wash., D.C. (July 14, 2016).

162 Id.

163 Id.

164 Id. 
it is not, and the intake officer would counsel the charging party not to file a case. The third task is labeling the case either an A, B, or C. ${ }^{165}$ For practical purposes, a charge will be labeled an A if: (1) it fits into the national enforcement plan (systemic discrimination, transgender or orientation, religious accommodation) or the EEOC wants to litigate it (for example, a class action or an outrageous accusation). ${ }^{166}$ Garden variety cases, a "he said, she said," an unfair discharge, or failure to hire claim will be a B case. The EEOC labels a case a $\mathrm{C}$ when it is "self-defeating" - that is to say that because of facts and law, it is destined to be dismissed. ${ }^{167}$

The priority enforcement plan was a good faith and effective method for the EEOC to move away from its prior policy of fully investigating every charge. Full investigation for all charges, in theory, seems to be a fair and equitable policy. In reality, it grinded the EEOC system to a halt. Legitimate charges would sit for years as investigators wasted time on charges that clearly had no merit. Something had to be done. It was, and it has worked. As stated above, the EEOC's handling of those cases it litigates is to be lauded. The problem lies with A charges that are not litigated, and the $\mathrm{B}$ and the $\mathrm{C}$ charges. The EEOC essentially dismisses $\mathrm{C}$ charges. Frankly, many of these charges should be dismissed. However, it seems likely that intake officers will make mistakes and these mistakes mean that some meritorious charges are essentially dead on arrival. Moreover, while some of these charges do not violate the law, society would be better off if the employer and the employee communicated and resolved the conflict instead of the EEOC simply dismissing the case without investigation. The EEOC does investigate and attempt to conciliate the non-litigated A cases and the B cases. The statistical reporting, unfortunately, reports all resolutions, so we cannot trace the different results for $\mathrm{A}, \mathrm{B}$, and $\mathrm{C}$ cases. Below, we report these statistics and provide a real-world timeline for a fully investigated charge.

In 2015, the EEOC resolved 92,641 cases. ${ }^{168}$ Of those resolved cases, 16,761 (18.1\%) were labeled as merit resolutions. Merit resolutions consist of cases where: (1) the EEOC found cause (3,239 or 3.5\%); (2) settled $(8,221$ or $8.9 \%)$; or (3) withdrew with benefits $(5,301$ or 5.7\%). ${ }^{169}$ After the EEOC finds "cause" it attempts to help the parties conciliate. Of the 3,239 conciliation attempts, the EEOC was successful 1,432 times and unsuccessful 1,807 times. Conversely, 65,880 (81.9\%) cases were determined to be without merit. Of those non-meritorious

165 Id.

$166 \mathrm{Id}$.

167 Id.

168 U.S. Equal Emp. Opportunity Comm'n, All Statutes FY 1997 - FY 2015 (2015), https://www1.eeoc.gov//eeoc/statistics/enforcement/all.cfm?renderforprint=1.

169 See id. 
cases, $60,440(65.2 \%)$ were the result of a no cause finding and 15,440 (16.7\%) cases were administratively closed. ${ }^{170}$ The results from 2015 were fairly typical. From 1997 to 2015 the percentage of merit resolutions ranged from a high of 22.90 in 2007 to a low of 11.00 in 1997. The late 19990's featured the three lowest years for merit resolutions: $11.00 \%, 12.40 \%$ and $16.50 \%$ respectfully. After 1999 eight of the fifteen years had merit resolutions above $20 \%$ and never lower than $17.20 \% .{ }^{171}$

These statistics beg the question: why are $77.1 \%$ to $89 \%$ of the cases deemed non-meritorious, and regardless of the answer to the first question, is this system the best use of EEOC time and resources? With regard to the reason the resolutions so starkly non-meritorious, one answer could be that the vast majority of cases are just that - without merit. Delving into the categories, however, one can question the administrative closings which ranged from $28.30 \%$ to $14.80 \%$ (16.7\% for a total of 15,440 in 2015). As stated above, administrative closings include cases where the charging party did not respond to EEOC communications or the EEOC could not locate the party. ${ }^{172}$ It is possible that in many of these cases the charging party simply got frustrated or could not pursue the case, because getting time off work to sue one's former employer is not a great career move. Of course, without examining each file, there is no way to know if any of the administratively closed cases had merit and "slipped through the cracks," but it does seem possible. The cases dismissed as having no cause ranged from $57.2 \%$ to $67.9 \%(65.2 \%$ in 2015). ${ }^{173}$ What is clear, we contend, is that investigating over one million charges that yielded no cause findings in nineteen years is not the best use of EEOC time and government money, and it does not yield justice. To support our contention, we must explain how full EEOC investigations really work.

The process of investigating $\mathrm{B}$ and $\mathrm{C}$ cases, according to numerous lawyers interviewed, proceeds as follows:

1. The charging party files a charge with the EEOC.

2. Within a short period of time, the EEOC notifies the employer that there is a charge, but states that no action is required.

170 Id. It should be noted that charges closed for administrative reasons include: failure to locate charging party, charging party failed to respond to EEOC communications, charging party refused to accept full relief, closed due to the outcome of related litigation which establishes a precedent that makes further processing of the charge futile, charging party requests withdrawal of a charge without receiving benefits or having resolved the issue, and no statutory jurisdiction exists.

171 Id.

172 Id.

173 See id. 
3. Approximately thirty days later, the employer receives a letter asking for a position statement and, if the employee desires, a request to mediate. The employer can accept or reject the mediation request. Regardless, the employer then negotiates for more time to file the position statement. It is standard to get 60 days to file. Assuming there is no mediation, the position statement is filed and now the case sits.

4. In most cases the parties will not hear from the EEOC for another 3 to 6 months until the employer receives a request for more information with a two-week deadline.

5. Assuming the employer complies, the case now site for another 6 months and then the EEOC issues a decision.

6. Thus, it takes the EEOC anywhere from 11 to 15 months to issue a finding of cause or no cause.

7. If the EEOC issues a cause finding the EEOC attempts to conciliate. This process takes less than one month. If the EEOC finds no cause, the employee can start the litigation process.

8. In $2015,16.7 \%$ of the charging parties did not get a resolution on the merits. Of the remaining $83.3 \%, 15.6 \%$ received benefits of some kind, and the remaining $67.7 \%$ (those who went through the whole process) can file in court eleven to fifteen months after complaining to the EEOC.

9. The litigation process takes anywhere from two to eight years and is expensive and time consuming. ${ }^{174}$

An examination of the EEOC's statistics provides a clear picture of the EEOC's investigation and conciliation processes' inability to provide justice. From 1997 to 2015, there were a total of 1,754,777 cases resolved. Of those resolutions, 1,182,041 reached the final stage and resulted in a determination of cause $(91,034)$ or no cause $(1,091,007)$. As stated above, the EEOC attempts to conciliate the cause findings - they were successful 27,111 times, or in about $30 \%$ of the cases. ${ }^{175}$ In the other 63,923 cause findings, the charging parties had to begin the litigation process. That is the same process that the 1,091,007 no cause charg-

174 Interview with Ilene W. Berman, Vice Chair, Taylor English Duma LLP (July 14, 2016); Interview with Gregg A. Gilman, Labor \& Emp't Practice Grp. Co-Chair, Davis \& Gilbert LLP (July 14, 2016); Interview with Paul E. Wagner, Shareholder, Stokes Wagner ALC (July 14, 2016).

175 U.S. Equal Emp. Opportunity Comm’n, All Statutes FY 1997 - FY 2015 (2015), https://www1.eeoc.gov//eeoc/statistics/enforcement/all.cfm?renderforprint=1. 
ing parties also had to begin. Thus, in about $70 \%$ of the cause findings, the charging party waits approximately one year just to have the right to file a lawsuit. Waiting eleven to fifteen months to get a resolution would barely be acceptable for people who are out of work and need their back pay. The eleven to fifteen months, however, for the vast majority of people, is just the beginning of the process.

Administratively closed cases also get "right to sue" letters. Since these cases did not go through the entire determination process, it is likely that the EEOC issued many of these letters in a shorter time frame than the eleven- to fifteen-month timeframe - indeed, after 180 days, the charging party can request a right to sue letter even if the EEOC has not finished its investigation. Thus, of the 1,754,777 charges resolved in the nineteen years available, only 262,867 (or about $15 \%$ ) received benefits. ${ }^{176}$ The remaining claimants waited at least six months, and more likely eleven to fifteen months simply to have the ability to file a lawsuit.

As bad as the EEOC process is, litigation can be much worse. First, it is expensive. The costs of litigation will almost always exceed $\$ 25,000$ and can be double, triple, or even five times as much for filing fees, deposition transcripts, experts, and other expenses. ${ }^{177}$ It also takes a lot of attorney time. Many plaintiffs' lawyers will, of course, take the case on contingency and thus, will only take a fee if they win. These lawyers, however, have to hedge their bet. They simply cannot work a case for years, put in hundreds of hours, put forward real money for expenses, and then allow the plaintiff to settle for back pay without fees, or worse, walk away before resolution. To ensure that plaintiffs do not walk away, most plaintiffs' lawyers demand that the employees have "skin in the game" by requiring a retainer of anywhere from $\$ 10,000$ to $\$ 20,000 .{ }^{178}$

In addition to the cost, litigation is an arduous process. There are numerous motions and other court appearances that the employee must take time off to attend. Depositions are stressful and often demeaning. The trial, if there is one, can go on for an extended time and is scheduled at the convenience of the court-not the parties. Moreover, it is often public and can damage the reputation of the employee, who in all likelihood will be looking for, or has found, another job. Finally, it takes too long a time to provide justice. In a study done by Theodore Eisenberg and Elizabeth Hill, it took on average, 709 days from the filing of the lawsuit until a verdict was reached. ${ }^{179}$ Adding on to the EEOC process, it

$176 \mathrm{Id}$

177 Interview with Ilene W. Berman, supra note 174; Interview with Gregg A. Gilman, supra note 174; Interview with Paul E. Wagner, supra note 174.

178 Sherwyn et al., Saving the Baby, supra note 1, at 33.

179 David Sherwyn et al., Assessing the Case for Employment Arbitration: A New Path for Empirical Research, 57 Stan. L. Rev. 1557, 1573 (2005) [hereinafter Sherwyn et al., New Path]. 
takes approximately three years to get to verdict. Worse, if the employee prevails, the employer can appeal and tie up the case for many more years. Indeed, if one were designing a system to get rid of discrimination and provide justice, it is at best unlikely, and more realistically, impossible, that anyone would advocate for the current system.

The final reason we contend that the agency and litigation model is a failed system is that the costs and delays create a perverse incentive that undermines good actors and benefits bad actors. The good actor employees who were discriminated against in B cases face years of delay and ultimately expensive litigation in order to be made whole. Thus, these employees, who need the money and do not have the time or resources to pursue litigation, have strong incentives to accept nuisance settlements even if their cases are strong. Indeed, many management lawyers report that they have, in fact, settled numerous cases that they would not recommend litigating for apologies and other non-monetary damages. ${ }^{180}$ In addition, these same lawyers report that they have settled what they perceive to be strong cases for a very small fraction of what the case is worth. Thus, the current system forces plaintiffs with strong cases to either walk away or accept a settlement that is not reflective of what the case is worth, benefitting bad actor employers. Similarly, the system benefits bad actor employees and hurts good actor employers. The bad actor employee files a charge and knows that the cost of a position statement, mediation, and other agency and litigation expenses will almost always exceed $\$ 10,000$ so that the employer has to make a decision - incur the expenses to prove a negative and have the costs of litigation hanging over its head, or provide de facto severance for the employees. ${ }^{181}$ Below, we provide a theoretical argument as to why we believe that EEOC/litigation is a poor system for resolving disputes.

\section{A Theoretical Framework to Contend that Employment Litigation is BAD FOR GoOd Actors AND GOOD FOR BAD ACTORS}

\section{A. The Haves Still Come Out Ahead}

The comparison to the reality of the agency and litigation process is the only comparison scholars should be making when contemplating whether, and to what extent, mandatory arbitration is the preferable method for adjudicating employment rights disputes. We contend that employment litigation is a poor forum for addressing most employment

180 Interview with Ilene W. Berman, supra note 174; Interview with Gregg A. Gilman, supra note 174; Interview with Paul E. Wagner, supra note 174. Additionally, the authors each have practiced employment law for years and have had this experience personally.

181 Sherwyn et al., Saving the Baby, supra note 1, at 98. 
disputes. The lower the compensation earned by the employee, the less likely it is that litigation would serve as a meaningful and legitimate method for obtaining redress. ${ }^{182}$ Similarly, the more likely an employer is to be a large, institutional repeat player in litigation, the more likely that employer will be able to exploit the legal system to its advantage in the short run, by avoiding paying damages owed in legitimate claims, and in the long run, by selecting only the best cases to pursue in litigation, maximizing the development of employer-friendly precedent. This is not a new idea. It is part of the set of ideas advanced in Marc Galanter's famous 1974 article, "Why the 'Haves' Come out Ahead: Speculations on the Limits of Legal Change." ${ }^{183}$ Litigation is the optimal forum for serving employers that wish to violate the rights of their employees and use the high barriers to entering the litigation system as a shield insulating them from liability, particularly against claims of lowincome employees.

\section{B. The Theoretical Framework for Dispute Resolution Fairness}

The authors' philosophical approach to dispute resolution for employment rights may differ from the approach of detractors of mandatory arbitration. The authors' primary goal is to increase the rate of harmonization of outcomes and objective truth with respect to violations of the law. That is, our aim is to maximize the rate at which employees who are actually wronged recover the damages to which they are entitled-not less, not more. Simultaneously, we are interested in minimizing the rate at which employers who have not violated the law are systematically incentivized to pay employees to avoid the costs of defending baseless claims. This could be characterized as a distributive justice focus. The authors are primarily interested in fairness as a function of equitable outcomes or awards. ${ }^{184} \mathrm{We}$ therefore prioritize processes that are fair over those that are unfair, but are more focused on de facto outcomes and the likelihood of dispute resolution outcomes aligning with the objective facts when determining whether an employee plaintiff is actually harmed in violation of the law. Along these lines, we explicitly prefer a process that permits access to an adjudicatory process over one that denies access to a percentage of employees, especially if the employees that are denied access are low-income earners. All else equal, these employees are more likely to need redress if they are economically harmed by employers violating their statutory employment rights. This is perhaps in alignment

182 See Sherwyn et al., Saving the Baby, supra note 1, at 92 n.102.

183 See Marc Galanter, Why the "Haves" Come Out Ahead: Speculations on the Limits of Legal Change, 9 Law \& Soc'y Rev. 95-160 (1974).

184 See, e.g., Robert Folger, Distributive and Procedural Justice: Combined Impact of 'Voice' and Improvement on Experienced Inequity, 35 J. Pers. \& Soc. Psych. 108 (1977). 
with Samuel Estreicher's characterization of the litigation system as a "Cadillac" available to a limited percentage of employees, as compared to mandatory arbitration, which is like a "Saturn," and thus more widely available, even if it lacks the fancy bells and whistles of the Cadillac. ${ }^{185}$ We prefer systems of adjudication that impose significantly lower barriers to entry, so that the employees earning the lowest possible pay are not left without a means to resolve a dispute. Directing a truly wronged lowwage earning employee to a courthouse, or to the EEOC, where the barriers to entry are too costly or too remote respectively, is the same as pointing to brick wall.

Secondly, and related to the first aim, the authors do not wish to expand or contract the scope of damages awardable to wronged employee plaintiffs. If the law permits a recovery of $X$ dollars when a finder of fact finds $\mathrm{Y}$ facts occurred, we strongly prefer a system of rights adjudication that most closely awards the wronged employee $\mathrm{X}$, not some multiple or fraction of $X$. This follows from the distributive justice focus described above. All else equal, an adjudicatory system of individual workplace rights that over-compensates employees is not a harmless model. Some could regard overcompensating wronged employees as a way that the legal system penalizes and disincentives employers from discriminating. This argument is an extension of the expressive function of the law. ${ }^{186}$ Employers view exorbitant jury awards for violations of Title VII (as an illustration), and then pay extra attention to avoid discriminating against other employees in a protected class. For this to happen as wished, only the marginal incentivization gained for the difference between the damages the employee should receive $(\mathrm{X})$, and what the jury over-awarded ( $\mathrm{X}+.5 \mathrm{X}$ for instance) should be evaluated as potentially increasing employer incentivization to avoid violating employees' rights. The question is therefore whether the average premium over-compensation awarded by juries to the employee (in this example, $.5 \mathrm{X})$ incentivizes improved employer behavior above what the $\mathrm{X}$ would have incentivized alone. This seems unlikely to produce the hypothesized effect, particularly because lost time and attorneys-fees associated with the action are fixed costs regardless of whether the jury awards $\mathrm{X}$ or $1.5 \mathrm{X}$. Therefore, the marginal improvement in behavior associated with overcompensation is likely not effective at changing the underlying behavior of employers who have already decided that discriminating is in their best interest at the lower price point. Further, even if the marginal

185 Samuel Estreicher, Saturns for Rickshaws: The Stakes in the Debate over Predispute Employment Arbitration Agreements, 16 OHio St. J. on Disp. Resol. 559, 563-64 (2001) (“A properly designed arbitration system . . . can do a better job of delivering accessible justice for average claimants than a litigation-based approach.").

186 Richard H. McAdams, A Focal Point Theory of Expressive Law, 86 VA. L. Rev. 1649, 1650-51 (2000). 
incentive for employers did produce the hypothesized effect (on the subpopulation of employers willing to consciously render employment decisions that violate the law), the marginal deterrent effect on employers ought to be weighed against the policy of encouraging an incorrect application of the law. All else equal, the authors would prefer a dispute resolution system for workplace rights that correctly compensates employees, and optimally incentivizes bad actor employers to avoid violating the law.

Lastly, the authors are equally concerned with Type-I and Type-II errors when adjudicating employment rights disputes. Type-I errors, or "false positive" results, in the context of employment rights adjudication, are those in which no violation of the law occurs, but the system of adjudication is nonetheless systematically more likely to reward an employee plaintiff that alleges employer wrongdoing. ${ }^{187}$ Type-I errors are not limited to only adjudicated cases. Non-meritorious cases that settle because the costs of defense exceed the costs of settlement are Type-I errors as well; plaintiffs, and their lawyers, are rewarded for bringing frivolous cases. Type-II errors, or "false negative" results, are those in which a violation of the law occurs, but the system of adjudication is nonetheless systematically less likely to reward an employee plaintiff that alleges employer wrongdoing. We include in Type-II errors "nuisance settlements" of legitimate cases where the money exchanged undervalues the harm the employee suffered. ${ }^{188}$ In Figure 1, Type-I errors are illustrated in the top right box in each of the four two-by-two tables, and Type-II errors are illustrated in the bottom-left box in each of these two-by-two tables.

187 Joseph L. Gastwirth, Statistical Issues Arising in Equal Employment Litigation, 36 JURIMETRICS J. 353, 368 (1996).

188 A nuisance settlement is a low-dollar figure settlement that the employer agrees to in order to avoid the time and expense of litigation. Attorneys Berman, Gilman, and Wagner report that they that have seen numerous cases that could have value settled for nuisance amounts because of time and expenses of the system forced the employee to "give in." Interview with Ilene W. Berman, supra note 174; Interview with Gregg A. Gilman, supra note 174; Interview with Paul E. Wagner, supra note 174. 
High Value Claims $(>\$ 100,000)$
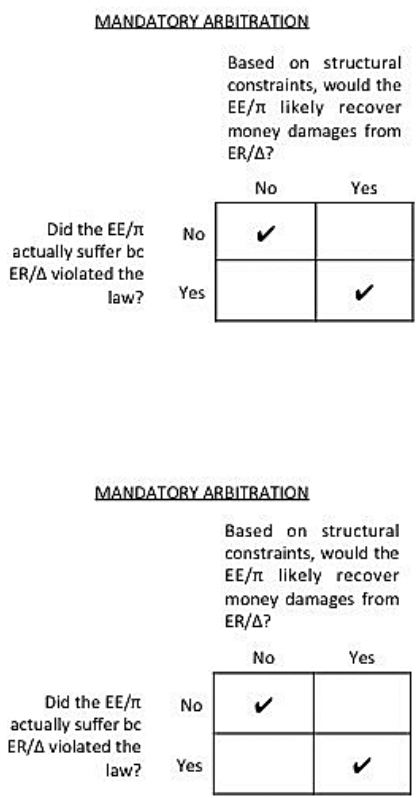

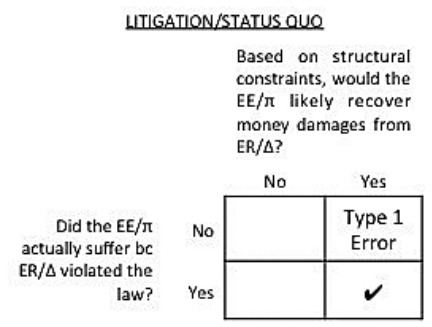

Low Value Claims $(<\$ 10,000)$

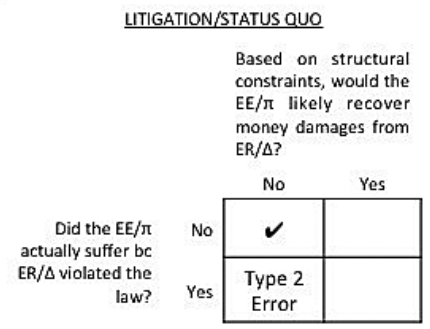

We equally weigh the sources of mismatching between violations of the law and compensation for those violations (in the form of settlement money or awards), and therefore regard an adjudicatory system of rights that avoids both types as "better" than an adjudicatory system that does not avoid either, or a system that incentivizes Type-I errors. We refer to the view of Type-I errors as favorable in the employment context as the "Robin Hood effect." Some commentators may regard employers paying out more money than they should to employee plaintiffs as positive, because it redistributes wealth from "greedy" corporate employers to individuals. ${ }^{189}$ Those in favor of redistribution assert that even if the specific individual employee was not legitimately wronged by the employer as alleged, this is a minimal problem if and when it occurs, because it is a tolerable downside of a litigation system that tends to favor employers. ${ }^{190}$ Essentially, it levels an unlevel playing field.

We are not convinced that Type-I errors should be tolerated or desired in employment litigation. We argue that there may be significant undesirable social costs associated with the "Robin Hood effect" of Type-I errors in employment litigation that detractors of mandatory arbitration are underestimating, or not estimating at all. Specifically, Type-I errors may incentivize unlawful discrimination in hiring. It is difficult to

189 See generally Daphna Lewinsohn-Zamir, In Defense of Redistribution Through Private Law, 91 Minn. L. Rev. 326 (2006).

190 See id. at 349-53. 
prove discrimination in hiring. Such cases make up a small percentage of the total cases filed. ${ }^{191}$ For instance, it is extremely hard to prove that an employer failed to hire someone because of his or her protected status. Aside from problems with proof, it is also less likely that an employee would observe discrimination at the hiring stage than at a later employment stage, such as promotion or termination. Because transaction costs are high in litigation, high wage earning employees in protected categories are shielded by the availability of Type-I errors and the fear of the "Robin Hood effect." Employers may become wary of hiring individuals in protected categories into higher-paying positions as a direct result of this justifiable fear.

Detractors may respond by suggesting that Type-I errors do not occur with sufficient frequency to merit the response we suggest in this Article. We think that Type-I errors occur frequently because of the structural incentives for them in litigation for high-value claims. In the end, this is an unaddressed empirical question. ${ }^{192}$ However, there are systematic structural differences between the two forums worth describing, in order to illustrate the relative likelihoods of Type-I and Type-II errors occurring.

For the sake of illustration, in Figure 1 we refer to amounts greater than $\$ 100,000$ as "high-value" claims, and amounts less than $\$ 10,000$ as "low-value" claims. ${ }^{193}$ In high value claims, in both litigation and arbitration, when an employee actually suffers a wrong, he is likely to be compensated for it - either through settlement or receipt of a favorable award exceeding the costs paid to obtain the result. Perhaps litigation over-compensates by redistribution, and we suggest above that this is problematic also. But, even if one overlooks this, or prefers redistributive private law sanctioning, the main difference between arbitration and litigation of high-value claims is the greater structural likelihood of Type-I errors in litigation. For instance, an employee who throws a chair at his manager and is promptly fired, who makes $\$ 200,000$ per year, and who

191 John J. Donohue III \& Peter Siegelman, The Changing Nature of Employment Discrimination Litigation, 43 Stan. L. Rev. 983, 1027 (1991) ("[U]nder the current regime in which firing cases vastly outweigh hiring cases, Title VII may generate a net disincentive for employers to hire protected workers.").

192 Both authors have had conversations with defense-side counsel and in-house counsel about the extent to which they perceive that Type-I errors occur in litigation. All of these individuals perceive that a high volume of the claims brought have a low likelihood of plaintiff success on the merits, but are nonetheless brought as viable settle-able claims because of the high costs of defense. Obviously, this is anecdotal evidence, and should be treated as such.

193 These are somewhat arbitrary amounts, derived from approximate high and low estimates of costs of defending a motion to dismiss. The middle-ground between $\$ 10,000$ and $\$ 100,000$ is purposely left unaccounted for. These numbers are placeholders for the real cutoffs for the effects described, and could be empirically derived or theoretically modeled with greater precision. This is not done here in the interest of pithiness. 
is able to overcome the low thresholds for satisfying the requirements of a prima facie case of discrimination will be able to sue and propose settling for slightly less than the employer would have to pay to defend the baseless suit. This unwronged employee is likely to get compensated to avoid the high costs of litigation. A bad actor employee wins, and a good actor employer loses, perhaps dis-incentivizing this employer from hiring future employees in the same protected class or other protected classes. With arbitration in place, the costs of adjudicating the same dispute are lower. ${ }^{194}$ The employer is less likely to settle, and the unwronged employee is more likely to receive no compensation. So, for higher value claims, arbitration is a structurally superior forum compared to the realistic version of litigation. ${ }^{195}$

Figure 1 also shows that arbitration is a superior forum for lower value claims more likely brought by low wage earners. In both forums, when plaintiff employees bring a baseless claim, they are unlikely to recover. In litigation, low-dollar value claims with no merit have nothing attractive about them to plaintiff-side lawyers, and they are therefore below the cost threshold, making it worthwhile to take on the case. In arbitration, it may actually cost more to bat away baseless low-dollar value claims. This is because arbitrating a baseless claim costs more than turning away a baseless claim in a plaintiffs' lawyer's office. Additionally, claims with low-dollar values are more likely to be brought in arbitration than in litigation. ${ }^{196}$ For employees with legitimate low-dollar value claims of discrimination, in litigation, plaintiffs' lawyers are unlikely to represent this person, and the EEOC is unlikely to step in. In arbitration, however, the simplicity of the forum, and the fact that most arbitration policies provide that the employer will not bring counsel if the employee does not, allow plaintiffs to represent themselves pro se. These employees get "their day," regardless of merit. Moreover, plaintiffs' lawyers who seek to legitimately represent aggrieved employees should be satisfied with getting their hourly rate if they prevail, because the time and expense to arbitrate a case is low enough that an hourly rate for victory is

194 See Sherwyn et al., New Path, supra note 179, at 1560.

195 An additional related benefit of arbitration as compared to litigation is the reduced incentive for plaintiff-side employment lawyers to recast non-meritorious, but highly valued, claims into claims of discrimination to leverage settlement. In litigation, if the chair-throwing employee comes to a lawyer and says that he was treated unfairly, but not because of his membership in a protected class, a lawyer may be incentivized to recast the claim of unfair treatment as discriminatory.

196 According to Senior Counsel for Labor and Employment at General Electric, Bobby Simpson, who administers GE's multi-step ADR program which culminates in binding arbitration, a serious risk of mandatory arbitration is that meritorious and frivolous claims get equal treatment, and that less screening results in more arbitration of claims that would have otherwise been dismissed on a motion in litigation, or not even sufficiently formed the basis of a complaint. 
not the unreasonable risk it is in litigation, which can take two to ten years and cost tens of thousands of dollars in expenses. ${ }^{197}$

Because the likelihood of Type-II errors is significantly worse in litigation than in arbitration, it seems likely that the structural arguments favor arbitration. Despite the logic of supporting arbitration as preferred method for employees, the bulk of academic work attacks arbitration and, therefore implicitly, supports the agency/litigation model. To support their arguments, scholars rely on empirical studies that are, we contend, flawed.

\section{The Empirical Studies}

Over the last twenty years, most scholars interested in workplace dispute resolution have attacked arbitration. ${ }^{198}$ First, in the early years after Gilmer, critics asserted that arbitration policies were unfair to employees because of structural biases such as reduction of damages, lack of mutual selection of arbitrators, and other procedurally flawed components of employment policies. ${ }^{199}$ Next, critics made a macro argument that arbitration prevents the development of the law because of private, non-precedential decision rendering. ${ }^{200}$ Finally, critics contended that arbitration is unfair to employees because it robs them of their right to a trial in order to be employed, ${ }^{201}$ that arbitrators are more likely to side with employers than employees because employers are "repeat play-

197 See generally Sherwyn et. al., New Path, supra note 179, at 1579.

198 See, e.g., David S. Schwartz, Mandatory Arbitration and Fairness, 84 Notre Dame L. REv. 1247, 1247, 1254 (2009) (explaining that there are three types of "fairness" concerns in the debate over mandatory arbitration clauses: process, outcome, and access); Alexander J.S. Colvin, Employment Arbitration: Empirical Findings and Research Needs, 64-OCT DisP. Resol. J. 6, 6 (2009) ("There is vociferous opposition to employers forcing pre-dispute arbitration agreements on employees."). There are three types of "fairness" concerns in the debate over mandatory arbitration clauses: process, outcome, and access. Id. at 1254; see also Scott Baker, A Risk-Based Approach to Mandatory Arbitration, 83 OR. L. Rev. 861, 891 n.2 (2004) (providing a non-exhaustive list of works critiquing mandatory arbitration).

199 See generally Schwartz, supra note 198, at 1254-57.

200 See, e.g., U.S. Equal Emp't Opportunity Comm'n, EEOC Policy Statement on Mandatory Binding Arbitration of Employment Discrimination Disputes as a Condition of Employment pt. V(A)(2) (EEOC Notice No. 915.002) (July 10, 1997); see also Harry T. Edwards, Where Are We Heading with Mandatory Arbitration of Statutory Claims in Employment?, 16 GA. ST. U. L. REv. 293, 296 (1999) (arguing that a decrease in published judicial opinions could negatively affect the development of the legal doctrine).

201 See, e.g., Alexander J.S. Colvin, Empirical Research on Employment Arbitration: Clarity Amidst the Sound and Fury?, 11 Emp. RTs. \& EMP. PoL'y J. 405, 406, 406 n.3 (2007) [hereinafter Colvin, Clarity Amidst the Sound and Fury] (citing Katherine Van Wezel Stone, Mandatory Arbitration of Individual Employment Rights: The Yellow Dog Contract of the 1990s, 73 DEN. U. L. REv. 1017, 1019-20 (1996) (arguing that mandatory arbitration clauses in hiring agreements raise due process concerns because employees "lack bargaining power and are needful of employment")). 
ers," ${ }^{202}$ and that arbitrators award lower damages to employees than juries. ${ }^{203}$

The first two arguments quickly lost luster. First, both courts and the arbitration community established protocols for procedural fairness, ${ }^{204}$ and thus, the early and somewhat outrageous policies that, for example, limited damages or had a company manager as the arbitrator, are not enforceable in any court. The "development of the law" argument fails because the current system is designed specifically to not develop the law. As stated above, the EEOC resolves close to 100,000 per cases per year. ${ }^{205}$ State agencies resolve a similar number. Despite nearly 200,000 cases resolved each year, there are only approximately 20,000 cases fielded in federal court each year. Of those 20,000 cases, fewer than $10 \%$ are resolved by trial or dispositive motion. It is difficult to criticize arbitration, which issues written opinions, for failing to develop the law, when the vast majority of EEOC charges are resolved privately with no precedential effect. ${ }^{206}$ It is even more problematic to force 200,000 claimants per year to endure an inefficient and ineffective system so that less than $1 \%$ of the cases will have the potential to "make new law." The next and ongoing wave of anti-arbitration scholarship purports to be supported by empirical studies. Below, we examine these studies and contend that they do not support litigation over arbitration and in fact, arbitration compares very favorably.

The empirical studies may be divided into three categories: (1) those that compare plaintiff loss rates in arbitration to litigation; (2) those that compare damage awards in arbitration to litigation; and (3) those that analyze arbitration as a forum compared to hypothetical base rates of information, such as how frequently an employer should win discrimination cases or other metrics. ${ }^{207}$ In the third category, scholars compare

202 See, e.g., Lisa B. Bingham, On Repeat Players, Adhesive Contracts, and the Use of Statistics in Judicial Review of Employment Arbitration Awards, 29 McGeorge L. Rev. 223, 238-39 (1998) (finding that employees arbitrating against a repeat-player lose more frequently) [hereinafter Bingham, On Repeat Players].

203 Lisa B. Bingham, Employment Arbitration: The Repeat Player Effect, 1 EmP. RTs. \& EMP. PoL'y J. 189, 199-200 (1997) (showing evidence that awards may be lower in arbitration than in litigation) [hereinafter Bingham, Repeat Player Effect].

204 See generally Comm'n on the Future of Worker-Mgmt. Relations, The Dunlop Commission on the Future of Worker-Management Relations: Final Report (Dep't of Labor 1994). For further discussion on due process protocols in the arbitration field, see Bingham, On Repeat Players, supra note 202, at 229-31.

205 See Comm'n on the Future of Worker-Mgmt. Relations, supra note 204, at 50.

206 See Administrative Enforcement and Litigation, EEOC, http://www.eeoc.gov/eeoc/en forcement_litigation.cfm (last visited Oct. 27, 2013) (stating that the Commission often resolves charges through "conciliation or other informal methods").

207 See generally Sherwyn et al., New Path, supra note 179, at 1567-76 (citing Theodore Eisenberg \& Elizabeth Hill, Employment Arbitration and Litigation: An Empirical Comparison (N.Y. Univ. Sch. of Law, Public Law and Legal Theory Paper Series, Research Paper No. 65, 2003); Elizabeth Hill, Due Process at Low Cost: An Empirical Study of Employment Arbi- 
arbitration results of employers who are "repeat players" (i.e. employers who have more than one arbitration) and repeat players with the same arbitrator to results from so-called single player employers and employers who are before an arbitrator for the first time. ${ }^{208}$ As described in more detail below, the findings from these studies either lend no support to the argument that arbitrators unfairly decide cases or, in some cases, they unwittingly lend support for mandatory arbitration as a forum that augments access for those who would not otherwise be able to bring their claims without mandatory arbitration in place.

The first and most important argument that undermines the empirical studies of arbitration as compared to litigation is the lack of salient base rate information on expected win rates. We do not know how many cases that make it to adjudication have merit. If $90 \%$ have merit, then the forum with results closest to a $90 \%$ employee win rate is the most just. If $10 \%$ have merit, then that is the employee win rate a just forum should yield. Assuming that a just forum would yield a 50\% win-rate for employees is simplistic and unrealistic. This assumption fails to account for asymmetric information availability about the validity of cases. Employers settle cases with bad facts at early stages. Another indication of expected rates of meritorious claims is the EEOC's classifications of merit and non-merit resolutions. All settlements, even nuisance settlements of $\$ 100$, are classified as merit resolutions. As stated above, in the last fifteen years the EEOC classified at least $80 \%$, and some years as much as $90 \%$, as being non-merit resolutions. Should the EEOC non-merit resolutions be the baseline? In other words, should employers prevail in over $80 \%$ of the cases?

Along these same lines, scholars compare damages awards. Again, there is no baseline. Are damage demands a fiction set forth by a plaintiffs' lawyer trying to increase the cases' value or a legitimate calculation of back pay? Is back pay reduced in arbitration because of the speed of the process? Do juries award punitive damages regardless of the law's requirements that the conduct be reckless or malicious as well as intentional? Do reported jury verdicts include damage awards that surpass the statutory punitive limit of $\$ 300,000$ because juries are not told about such limits? Of course, judges automatically remit these awards, a step

tration Under the Auspices of the American Arbitration Association, 18 Онго Sт. J. Disp. Resol. 777 (2003); Estreicher, supra note 185, at 1569; Lewis L. Maltby, Private Justice: Employment Arbitration and Civil Rights, 30 Colum. Hum. RTs. L. Rev. 29 (1998); Bingham, Repeat Player Effect, supra note 203; William M. Howard, Arbitrating Claims of Employment Discrimination: What Really Does Happen? What Really Should Happen?, DisP. Resol. J., Oct.-Dec. 1995, at 40.

208 See Bingham, On Repeat Players, supra note 202, at 223, 237; see also Sherwyn et. al., New Path, supra note 179, at 1570-72 (discussing Lisa Bingham's empirical study on the effects of repeat-players on arbitration results). 
that is not necessary because arbitrators are aware of these limits. What percentage of "good cases" do the EEOC and dispute resolution steps weed out? Do only higher award cases make it to court? While certain scholars do attempt to examine some of these questions, the data simply does not provide enough answers to make a real comparison.

Finally, and most importantly, the comparisons are taking different cases and implying that the forum dictates results. Having one case adjudicated in arbitration and one in litigation does not tell us the legitimacy of the forums. Neither does having 1,000 cases in each forum. These are different cases, under different laws, with different cost structures, different barriers to entry, and different time frames. At the end of the day, all we can tell from these descriptive statistics is what the means and medians are with respect to win/loss rates, time, damages, costs, and fees. These means and medians do not inform us of justice. In fact, the only means and medians that provide any useful information are those associated with time and costs. While it is possible that the cases litigated are more complex than those arbitrated, and that is why time and fees are longer and higher, the fact that arbitration features less discovery, fewer motions, and no year-long EEOC wait allows us to infer that arbitration is faster and less expensive.

Cases that are litigated are filed with the EEOC or state agencies before going to court. Arbitration cases are not. It is our understanding of existing empirical work that the percentage of litigated cases deemed meritorious by the EEOC that nonetheless lose in court is not reported. However, the whole bundle of arbitration cases is compared to litigation results to conclude that arbitration is unfair. This obvious thumb on the scale weighting is not a useful exercise from which to draw this conclusion.

There are two basic selection effect problems that plague empirical comparisons of arbitration to litigation. First is the existence of structural differences between arbitration and litigation such as motion practices. Most arbitration policies do not allow for motions to dismiss or summary judgment motions. ${ }^{209}$ These dispositive motions eliminate a huge percentage of meritless cases from the litigation process. ${ }^{210}$ So, the universe of arbitration cases includes more cases in which employees should lose

209 See Sherwyn et. al., New Path, supra note 179, at 1569 (discussing how including "[a]rbitration cases that could have been decided by motion, had the matter been in litigation rather than arbitration" in the data lowers employee win rates).

210 See Laura Beth Nielsen \& Robert L. Nelson, Rights Realized? An Empirical Analysis of Employment Discrimination Litigation as a Claiming System, 2005 Wis. L. Rev. 663, 681, 694 tbls. 2.A \& 2.B; see also Laura Beth Nielsen \& Robert L. Nelson, Scaling the Pyramid: A Sociolegal Model of Employment Discrimination Litigation, HANDBOOK OF EMPLOYMENT DisCRIMINATION ReseARCH 1, 3-34 (Laura Beth Nielsen \& Robert L. Nelson eds., 2008). 
because they are not screened out in motions. ${ }^{211}$ Second, the cost of bringing a complaint in arbitration is much lower than the cost of bringing a complaint in court. ${ }^{212}$ So, holding constant the merits of a claim, a plaintiff is more likely to bring his claim to arbitration compared to litigation. Again, more claims with weaker facts supporting plaintiffs' cases, and lower-value claims will be systematically more prevalent in the pool of arbitration cases relative to the pool of litigated cases. Rational plaintiffs' lawyers do not, and should not, risk their time on cases with a low probability of success. Lawyers may take cases with weaker merits in an arbitration forum. We do not have any direct evidence that this is the case. We do, however, believe that arbitration is friendlier to pro se employees, based on our personal experiences with employers who have implemented mandatory arbitration. Employers such as Darden Restaurants, General Electric, and Halliburton will not have a lawyer arbitrate the case if the employee is pro se and/or have an employee benefit plan whereby the employee selects an attorney and the company pays for all or a portion of the fees. We know of no employer that will not use an attorney if the employee is pro se nor do we know any employer that helps defray litigation costs and fees for its employees. Thus, it stands to reason that more marginal, or even meritless cases, make it into the arbitration process compared to litigation, because arbitration cases do not have to survive both dispositive motions and rational plaintiffs' lawyers case acceptance standards.

These problems could be corrected if the adjudicative forum were randomly assigned. It is our understanding that none of the studies purporting to demonstrate that mandatory arbitration is "worse" than litigation employs such a design. ${ }^{213}$

The next set of empirical research compares specific arbitration results to more general arbitration results. This scholarship examines the win/loss records of plaintiffs in arbitrations where the employer is a repeat player versus those where the employer is not a repeat player. ${ }^{214}$ These scholars define repeat players as employers who have had one more than one arbitration in the applicable data set. ${ }^{215}$ The double repeat

211 See supra note 81.

212 See Sherwyn et al., Saving the Baby, supra note 1, at 100 (stating that arbitration is less expensive than litigation partly because lawyers do not need to spend as much time to arbitrate as they would to litigate a court case); see also Sherwyn et al., New Path, supra note 179, at 1574-76 (generally comparing costs of arbitration and litigation).

213 See Sherwyn et al., New Path, supra note 179, at 1565, 1567 (providng a list of sources).

214 See Bingham, On Repeat Players, supra note 202; Bingham, Repeat Player Effect, supra note 203.

215 See generally Bingham, On Repeat Players, supra note 202; Bingham, Repeat Player Effect, supra note 203 (using "repeat player" most commonly to refer to employers who have had more than one arbitration in an applicable data set). 
player not only has arbitrated before, it has arbitrated before the same arbitrator. ${ }^{216}$ The reported findings of these studies are that repeat players may prevail more than non-repeat players (statistically significant) and double repeat players are more successful than repeat players (but not statically significant). ${ }^{217}$ The conclusion either implicitly or expressly stated is that arbitrators may favor the employer who can hire them in the future and, even more so, who hired them in the past. ${ }^{218}$

These studies do not demonstrate arbitrator bias, nor do they suggest that mandatory arbitration presents a forum likely to yield worse results for employees. First, repeat players are labeled repeat players when their second case is in the data set. ${ }^{219}$ Researchers include the first case in the repeat players' win/loss record. ${ }^{220}$ This placement begs the question: how did the arbitrator in the first case know the employer would be a repeat player? The answer provides a plausible reason to explain the repeat and double repeat player effects - repeat players are, in most cases, employers with arbitration policies affecting most of, if not the entire workforce. These employers are not only arbitrating one off "for cause" employment contracts with senior executives. Instead, they are arbitrating civil rights claims for their entire workforce. ${ }^{221}$ Such arbitrations are not, however, the first step in the process. Instead, every mandatory arbitration policy the authors have reviewed contains a multiple-step grievance procedure that includes some form of mediation or peer review adjudication process.222 Thus, the parties have, in many

216 Colvin refers to this "double repeat player" effect as the "repeat employer-arbitrator" effect. Colvin, supra note 201, at 430; see Sherwyn et al., New Path, supra note 179, at 1571, 1571 n.64 (citing Lisa Bingham's study in which she analyzed "repeat player" and "repeat arbitrator" cases and citing Lisa B. Bingham \& Shimon Sarraf, Employment Arbitration Before and After the Due Process Protocol for Mediation and Arbitration of Statutory Disputes Arising out of Employment: Preliminary Evidence That Self-Regulation Makes a Difference, in Proceeding of the NYU 53rd Annual Conference on Labor 303, 323 tbl.2 (Samuel Estreicher \& David Sherwyn eds., 2004)).

217 Bingham, Repeat Player Effect, supra note 203, at 213 (finding that "[e]mployees dealing with non-repeat player employers recovered on average $48 \%$ of what they demanded, while employees dealing with repeat player employers recovered only $11 \%$ of what they demanded"). See generally Colvin, supra note 201, at 430 ("Out of the same sample of 836 awards, employees won only fourteen out of the 124 cases (11.3 percent) involving a repeat employer-arbitrator pair, compared to 151 out of the 712 cases (21.2 percent) that did not involve a repeat employer-arbitrator pair, which was a statistically significant difference....").

218 Colvin, supra note 201, at 427.

219 See id. at $427-31$.

$220 I d$.

221 See Sherwyn et al., New Path, supra note 201, at 1570. One reason for finding that employees won less against repeat players was that "repeat players were arbitrating under an arbitration policy where employees were employed at will and had to prove that the employer violated state or federal law." Id.

222 Colvin, supra note 201, at 11 ("Case studies of companies that have adopted internal grievance procedures, such as internal management appeals boards, mediation, or peer review, 
cases, a non-adversarial, process that will allow for settlements or other type of resolution. Following a multi-step grievance process, an employer should never arbitrate a case it can lose. Thus, employers that have so many arbitrations that they are repeat and, in some case, maybe double repeat players, should have significantly better win records than non-repeat players. Similarly, experienced employers should have better win/loss records than inexperienced employers in litigation and before the EEOC.

Employers learn from their experiences. If an arbitrator at time 1 with plaintiff 1 expresses that she would be convinced that no discrimination occurred if the employer can produce $X$ type of evidence, the employer is more likely to pay attention to $\mathrm{X}$ type of evidence in presenting its case before the same arbitrator in the future. Similarly, it stands to reason that repeat player litigators know what judges are looking for in summary judgment motions and what juries rely on at trials. Do repeat player litigators fair better than non-repeat litigators? We contend that the proper comparison for repeat player employers in arbitration is repeat player employers in litigation. We know of such studies. It is, however, the authors' own experiences as practitioners that repeat players who know how to respond to the EEOC do better than those accused for the first time. In fact, we modestly, and sadly report, that our firms' and our experienced clients' knowledge of how "to play the EEOC game" allowed us to resolve claims of "guilty employers" with findings of no cause or of nuisance settlements. We further contend that we could never have attained such a result in front of any AAA, JAMS, or any other legitimate arbitrator. The authors of the repeat player studies do not even contemplate such a comparison. ${ }^{223}$ Instead, arbitration is pitted against, as we stated above, utopian litigation.

The easiest (and most plausible) explanation of why many "repeat player" employers win more often is that they should win more. Another name for "repeat players" that prevail in cases frequently could be "good/realistic employers" who tend not to violate the law and when the facts are bad, their experienced, risk averse lawyers, settle. Assuming that lower transactional costs for bringing cases increases the volume of meritless (and more questionable, but possibly meritorious) cases brought against employers with arbitration agreements in place, good/ realistic employers would nonetheless face a higher volume of claims, which, they would win when arbitrated. Good/realistic employers should win more claims. Evidence that the arbitrator ruled in favor of an employer at time 1 with plaintiff 1 could be interpreted as the correct result,

along with employment arbitration suggest that they can resolve many cases, with potential advantages from both the employees and the organization's point of view.").

223 See, e.g., Bingham, On Repeat Players, supra note 202; Colvin, supra note 201. 
which means that all else equal, perhaps this employer does a good job of complying with the law and settles when it does not. So, with plaintiff 2 at time 2, one would expect the same result. The repeat player effect is more appropriately interpreted as evidence that arbitration is working-it is permitting employees with weaker or meritless claims their opportunity for "voice" and correctly sorting out the bad claims that we don't observe in litigation because they are likely screened out by plaintiff-side lawyers or in motion practice. Even if one erroneously believes that employers are only more likely to have a time- 2 or plaintiff- 2 if they behave illegally, the conclusion that arbitrators are biased against employers based on the repeat player data is incorrect because one cannot (and should not) rule out the possibility that arbitrators are getting it right in their rulings because repeat players should win more often, and we do not observe non-repeat player win rates to compare.

Professor Alex Colvin studied 449 arbitration cases. ${ }^{224}$ Cases adjudicated in arbitration had almost identical means and medians - 367 days. Professor Colvin also provides the mean and median awards for those employer-promulgated policies versus individual negotiated contracts. The value of such comparisons is limited at best. For example, Colvin reports that the win rate for individual contracts is $64.6 \%$ versus $24.7 \%$ for employer-promulgated policies. He hypothesizes that the difference may be explained by increased sophistication, access to better counsel or the fact that contractual claims are easier to prevail on than statutory claims. At first blush, reason three seems the most persuasive in employment cases employers have the burden of proving just cause and employees have to prove discrimination. Clearly, it is much more difficult to prove just cause than to prevent an employee from proving discrimination. As stated above, employers who are sophisticated enough to have a company-wide arbitration policy are competent enough to evaluate cases and avoid the smoking gun often needed to prove discrimination. Moreover, not paying an employee their contractually required damages is limited to the amount owed - there are not attorneys' fees, costs, or punitive damages. A high damage award and limited extra costs could incentivize employers to refuse to pay the demanded amount and force the employee to arbitrate. In addition, the definition of cause can result in good faith disputes (e.g. did having a consensual affair with a paid intern violate the moral turpitude clause; is poor performance in the great recession cause). Losing a good faith dispute does not create the friction costs of being labeled a discriminator, thus, the risk of arbitrating is reduced. On the employee side, those with individual contracts are almost always high-wage earners who either can, or must, not get a new

224 Alexander J.S. Colvin, Mandatory Arbitration and Inequality of Justice in Employment, 35 Berkeley J. EMP'T \& LAB. L. 71 (2014). 
job right away, and they have the means to pursue their cases. This makes a settlement less likely. In other words, comparing the results of employer-promulgated policies versus individual contracts proves one thing - these cases are different and there is no useful comparison between the two.

Putting it all together, Colvin finds that many of the claims from employer-promulgated policies are for high wage earners who have attorneys. He also finds that motion practice is on the rise and settlements resolve the majority of cases. Colvin, a long-time critic of arbitration, seemingly dismisses one of the benefits of arbitration by stating the typical time of arbitration, one year, is only a year shorter than typical litigation-a $100 \%$ difference. Of course, left out of this comparison is the fact that typical litigation often begins after anywhere from six months to two years of EEOC time prior to trial and can include years of appeals after. He then states there are lower win rates in arbitration than litigation-a statement that even if true (and it can be disputed), it is at best, superficial, and more likely in reality, an irrelevant statement. He then concludes that his results call in to question arbitration's claim of providing access to justice for low-wage workers because, while not as bad as litigation, it's too much like litigation.

Colvin's conclusion brings one back to the great debates over labor arbitration by Derek Bok and Archibald Cox-should arbitration be more or less legal?225 It may be better if arbitration were less legal, but unlike those labor arbitration debates, we are dealing with statutory rights and high damage awards. Thus, the legend that great labor leaders could hear a piece of an arbitration argument and then make off the cuff decisions is less appealing. Assuming arbitration is, however, "too legal," it is still much less problematic than the agency and litigation process. With employer-promulgated policies, the facts are that arbitration: (1) is significantly faster; (2) is easier for, and has more, pro se plaintiffs; (3) almost always includes in-house dispute resolution programs that resolve cases in less adversarial method; and (4) according to the Stanford article, ${ }^{226}$ results in the vast majority of claimants remaining employed. The goal of the employment adjudication system is to eliminate discrimination in the workplace and to ensure that employers comply with applicable labor and employment laws. Instead of trying to shoehorn

225 See Derek C. Bok, The Regulation of Campaign Tactics in Representation Elections under the National Labor Relations Act, 78 HARv. L. Rev. 38 (1964); Archibald Cox \& John Dunlop, Regulation of Collective Bargaining by the National Labor Relations Board, 63 Harv. L. Rev. 389 (1950); Archibald Cox, Strikes, Picketing and the Constitution, 4 VAnd. L. Rev. 574 (1951); Archibald Cox, Federalism in the Law of Labor Relations, 67 HARV. L. Rev. (1954); Archibald Cox, Grievance Arbitration in the Federal Courts, 67 Harv. L. Rev. 591 (1954); Archibald Cox, Reflections Upon Labor Arbitration, 72 HARv. L. Rev. 1482 (1959).

226 See Sherwyn et al., New Path, supra note 179, at 1589. 
employment disputes into an overloaded court system with rules that are not designed for the everyday interactions that result in workplace disputes, we suggest continued focus on development of fair and neutral arbitration based systems that address legitimate concerns with privatized employment dispute resolution.

While we conclude that that arbitration is better than the alternative agency and litigation process, we also accept that arbitration is far from perfect. We contend, however that makes more sense to improve private ADR systems which, instead of trying to eliminate this superior, but flawed, system in favor of the agency and litigation process - an awful system that cannot be fixed

\section{The Remedy}

Arbitration is not a panacea. However, even in its partially unregulated form, it is still better than litigation if the operative measure of success is justifiable and fair outcomes for employers and employees. Litigation's woes are less likely surmountable than arbitration. Therefore, we suggest working on overcoming mandatory arbitration's faults in as meaningful a way as possible.

Litigation is a poor system for fairly addressing employment disputes.

Attempts to make litigation more employment dispute friendly will likely have negative effects on other areas of the law. It would involve restructuring a system that pre-dates the Constitution, is provided for in the Constitution, and is so vast that it is simply beyond comprehension. Mandatory arbitration of employment disputes, however, can be systematically revamped in a meaningful way that improves outcomes and processes for claimants and increases the odds of producing just results.

In order to begin to address the concerns over arbitration, there must be both new legislation, and administrative agencies to enforce and implement those laws. While proposing legislation in the current political environment often seems comical, that cannot compel scholars and advocates to refrain from thoughtful creativity in favor of a seriously flawed status quo. Before we provide our solutions, we need to identify the problems.

We split the "problems" with arbitration into three categories: (1) protocol problems; (2) real, or imaginary, arbitrator neutrality problems; and (3) structural problems. Below we quickly identify the problems with arbitration and then provide the fix.

\section{A. Due Process}

As stated above, for years, anti-arbitration scholars argue that arbitration policies are unfair despite the fact that most, if not all of these 
problems have been resolved. ${ }^{227}$ It is interesting because almost all arbitration policies, like union grievance procedures, provide parties with several steps to discuss and resolve issues before they reach arbitration. Indeed, in our 2004 study of a large employer with a mature ADR/arbitration policy, less than $10 \%$ of the cases went to arbitration, more than $90 \%$ of the claims were resolved in one week or less, and more than $90 \%$ of the employees remained employed. ${ }^{228}$ Not surprisingly, arbitration critics ignore or downplay the benefits of ADR inherent in most policies and focus on the unfairness of rogue policies. Indeed, there have been policies, some of which were upheld by courts, that limited awardable damages, provide for unilateral selection of the arbitrator by the employer, or contain other untenable procedures. Those who attacked these policies were correct and the courts have responded by declaring those arbitration policies as unenforceable.

While it is clear that for the most part, protocol problems have been fixed. Legislation could easily solve all protocol concerns by simply following the due process "protocol" and the several court opinions requiring that arbitration policies provide for the following: (1) written opinions, (2) choice of arbitrator through the AAA, JAMS, or another approved agency; (3) defined discovery;229 (4) statutory damages; (5) defined expenses ${ }^{230}$; and (6) clear communication of the policy so that employees are aware of the policy, understand how it operates, and have access to its adjudication process. This could be achieved by requiring that the policy be in a stand-alone document that employees have adequate time to read and understand. ${ }^{231}$ Arbitration policies that failed to satisfy the Mandatory Arbitration Act's protocol would be unenforceable.

227 See Comm'n on the Future of Worker-Mgmt. Relations, supra note 204; see also On Repeat Players, supra note 202 and accompanying text.

228 See Sherwyn et al., New Path, supra note 179, at 1587-89.

229 By defined discovery, we mean a set number of depositions, document requests, interrogatories, and a process for requesting more discovery if necessary.

230 There is debate over arbitration expenses. Some contend employers should pay all while others contend this would unduly influence arbitrators. In limited space we cannot fully address the debate other than to say the options are not vast, the problems not unique, and a solution can be found.

231 Of course, some may argue that the policy should be post-dispute voluntary. This defeats the purpose, as when a claim is ripe it is at best impractical, and more likely, impossible to find a situation where the employer and the employee would each choose arbitration. Instead, one side will almost always find strategic advantages in the inefficiencies of litigation. Similarly, pre-dispute voluntary arbitration policies simply provide an opt-out which very few employees invoke, so there is no real point. While there may be other protocol concerns that we did not mention, none of the issues that we have seen cannot be resolved. 


\section{B. Arbitrator Neutrality}

The arbitrator neutrality concerns are not easily identified and therefore are not simple to fix. As stated above, the main theory behind arbitrator neutrality issues is the concern that arbitrators will rule in favor of employers because employers will be repeat players and therefore represent future work for arbitrators. Above, we contested these conclusions. That said, perception is reality and this issue can be resolved.

The obvious answer is that the plaintiffs' bar will be repeat players too and thus, like a union, level the playing field. The arbitration critics claim this is not the case and hypothesize that arbitration employees have trouble getting counsel. This should not be the case. Because arbitration is faster and less expensive, plaintiffs' lawyers should prefer it over litigation. As far as we know there have been no studies showing that it is easier, or more difficult, for plaintiffs to find counsel in litigation as compared to arbitration. Indeed, Colvin criticizes arbitration because too many claimants have counsel (kind of an arguing both sides). Instead, as stated above, there are studies that show that plaintiffs' lawyers will refuse to take low wage cases and insist on large retainers for all but the strongest cases. If plaintiffs' lawyers will not take arbitration cases, there is a question that needs to addressed: do plaintiffs' lawyers only take high damage cases where they can use the costs of litigation to force a settlement, independent of the merits of the claims? If so, should we perpetuate such a system? Even if this is the case, we live in the information age. When one of the authors began practicing, he vetted arbitrators by accessing loose-leaf notebooks in law libraries that may or may not have had any information on the arbitrators selected in a panel. The internet has rectified this problem. Any lawyer and most employees can research arbitrators and view their prior awards. In any event, lawyers can contact arbitrators and gain additional information on their history of awards. But even more can be done if this is not sufficiently convincing.

First, we can develop a sophisticated "TripAdvisor"-like ${ }^{232}$ arbitrator rating system based on data analytics. The system, which the Cornell Institute for Hospitality Labor \& Employment Relations (CIHLER) would be willing to establish and administer, would provide reviews for arbitrators and allow employees to obtain relevant unbiased information that would seriously hamper any actual repeat player effects-if they exist. Second, the EEOC or the Department of Labor (DOL) can assign investigators or lawyers to guide employees and their counsel through the arbitration selection process. While choosing an arbitrator takes time, it does not take nearly the amount of time that investigating a case does.

232 TripAdvisor is a popular consumer review website for travel-related content, such as hotels and tours. See TripAdvisor, https://www.tripadvisor.com/ (last visited Dec. 10, 2016). 
EEOC and DOL resources would be well used as part of the selection process. Having the EEOC and DOL choose the arbitrator on behalf of the plaintiff would clearly level the playing field and end the repeat player debate.

\section{The Development of the Law}

An arbitration entity needs to need to publish arbitration awards. Currently, the redacted awards are available on Lexis. They are not available for free on the internet and they are somewhat difficult to access for the pro se inexperienced employees. Again, there is an easy fix. CIHLER is working to create a publicly available database of arbitration awards. We would be the depository of all arbitration awards, would redact the parties' names, and then would post them online. To make matters easier, CIHLER would create an index system so that employees and employers could easily research the relevant topic. CIHLER would also publish a yearly report on arbitration's development of the law. If the EEOC determined that arbitrators were "getting something wrong" (e.g. liability in sexual harassment cases or not applying the law regarding sexual stereotypes to transgender employees), or if it was not developing the law to the EEOC (e.g. religious accommodation), the EEOC could label such cases as A's and litigate them.

\section{Class Actions}

The most challenging arbitration issue concerns class actions. As we contend above, class actions benefit lawyers more than anyone else and are often not the best way to resolve systemic workplace disputes. The fact is that there are cases when it is best for the employees and society to have cases litigated by a class. The answer is somewhat simple-let the government litigate class actions. Before any case is resolved by arbitration, the EEOC and DOL class action development of law departments should review the facts and circumstances. If the appropriate government agency believes the case merits intervention, then the Agency can take the case on behalf of the employees. Even their harshest critics believe, as we clearly do, that the EEOC and DOL are effective litigants. In fact, as one prominent management lawyer stated with regard to an agency charge: "If the EEOC brings the lawsuit against your client—God help you." ${ }^{233}$ It is hypocritical to argue that the EEOC and the DOL cannot be trusted to select arbitrators or choose to litigate cases, but is perfectly competent to investigate and resolve all claims. The argument of limited resources is undermined by the fact that mass arbitration will greatly re-

233 The attorney, a partner at a major NYC labor and employment firm, stated this at the Tenth Annual Labor and Employment Law Roundtable at Cornell University, May 4, 2009. 
duce the amount of time needed to investigate claims and the resources can be redirected. Redirecting the majority of cases to arbitration will free up resources at the EEOC and DOL to allow the Agencies to do what they do best-litigate class actions and other cases that should be in the courts for the public good.

\section{E. The Mandatory Arbitration Act (the MAA)}

The MAA, in its simplest form, would require:

1. Due Process Protocol as determined by statue;

2. A system for rating arbitrators administered by Cornell;

3. The EEOC/DOL to act as an advisor for employees seeking help with selecting an arbitrator;

4. That all policies expressly state that employees have the right to file with the EEOC/DOL and/or any other federal, state, or local agency. That agency would have thirty to forty-five days to decide to take the plaintiff and litigate the case on behalf of the employee. The Agency would have the right to file class actions; and

5. All other case would be deferred to arbitration.

\section{Conclusion}

The current system provides justice for a few, a windfall for some, and frustration and defeat for most. A system that is predicated on making those $1 \%, 2 \%,-5 \%$, that have suffered egregious harm, whole at the expense of the remaining $90 \%$ are either left of, or abused by, the process is not justice. Arbitration can provide justice!

The current agency and litigation model is awful for employees, especially low-wage earners. While the EEOC could change its process, there is no way to fix litigation. Instead of trying to destroy arbitration (and by extension perpetuate the current system), employee advocates and scholars should try to solve arbitrations problems while saving employees from litigation - a system that no honest employee, employee advocate, or scholar would ever propose or champion.

Essential to the authors' argument is that both Type-I and Type-II errors in employment dispute resolution should be equally weighted, and thus, equally avoided. Another part of the argument is that compared to the status quo of litigation, arbitration is a better system for avoiding both types of errors, and maximizing fair adjudication of employment disputes. In spite of the arguments in favor of mandatory arbitration, momentum has gained against it in the past two decades. It is generally hard to reverse momentum. Reversing academic momentum is no exception. 
The momentum against mandatory arbitration was born of flawed interpretations of empirical studies and unfair comparisons to an unrealistic utopia of litigation. Imagine a world in which there were no system in place resolving employment disputes. If Congress convened experts and academics, we believe it is unlikely that the consensus would be to create a system as flawed as the current system of litigation as a way of effectively and fairly addressing workplace rights disputes. The most likely result would be a forum of small tribunals of workplace-focused dispute resolution similar to models in Europe. 234

Imagine instead, that the default way of resolving disputes were mandatory arbitration. If all disputes were resolved this way, bad actor employers would likely vigorously lobby for litigation to replace arbitration as the default way of resolving employment disputes. Their argument would be predicated on fairness, because no one should be denied the right to a jury. The establishment of a litigation system would function as an illusory augmentation of employee rights, but the reality would be the creation of a very unlevel playing field that would advantage employers with more resources. Employees' rights advocates would highlight these facts and note that arbitration's lower cost thresholds permit adjudication of claims that could not be brought in litigation. The obvious result would be that under the proposed litigation system ("the Unlevel Playing Field"), employers would be more able to get away with violating the law, especially for lower earning employees. It is somewhat ironic that the momentum to ban mandatory arbitration is as often framed as an augmentation of employee rights. We hope the model of employment dispute resolution fairness suggested by this Article serves to slow, or better still, reverse the momentum against mandatory arbitration. Our hope is to point academics and lawmakers in a more productive direction of regulating mandatory arbitration to maximize its transparency and fairness and provide justice.

234 See Samuel Estreicher \& Zev J. Eigen, The Forum for Adjudication of Employment Disputes in Research Handbook on the Economics of Labor and EmployMENT 409, 419-20 (Michael L. Wachter \& Cynthia Estlund eds., 2012). 
